University of Wollongong

Research Online

Scopus Harvesting Series

$1-12-2021$

\title{
Experimental Study of GFRP-Reinforced Geopolymer Concrete Columns under Different Loading Conditions
}

\author{
Muhammad N S Hadi \\ University of Wollongong, mhadi@uow.edu.au \\ Shehroze Ali \\ University of Wollongong, sa217@uowmail.edu.au \\ M. N. Sheikh \\ University of Wollongong, msheikh@uow.edu.au
}

Follow this and additional works at: https://ro.uow.edu.au/test2021

\section{Recommended Citation}

Hadi, Muhammad N S; Ali, Shehroze; and Sheikh, M. N., "Experimental Study of GFRP-Reinforced Geopolymer Concrete Columns under Different Loading Conditions" (2021). Scopus Harvesting Series. 2661.

https://ro.uow.edu.au/test2021/2661

Research Online is the open access institutional repository for the University of Wollongong. For further information contact the UOW Library: research-pubs@uow.edu.au 


\title{
Experimental Study of GFRP-Reinforced Geopolymer Concrete Columns under Different Loading Conditions
}

\begin{abstract}
This study discusses the behavior of ambient-cured circular geopolymer concrete specimens tested under different loading conditions. Twelve specimens were cast and tested to investigate the influence of the type of the reinforcement, that is, steel and glass fiber-reinforced polymer (GFRP), the pitch of the transverse reinforcement, and loading conditions (concentric axial load, 15 and $35 \mathrm{~mm}$ eccentric load, and four-point bending). The axial load carrying capacity, confinement efficiency, and deformability of the specimens decreased for the replacement of the steel reinforcement with the same amount of GFRP reinforcement under concentric and eccentric loads. However, the deformability of the GFRP reinforced concrete (RC) specimen was higher than the deformability of its steel counterpart specimen under fourpoint bending. Overall, the reduction in the pitch of the GFRP helices in the GFRP-RC specimens resulted in a significant improvement in the confinement efficiency, deformability, postpeak behavior, and the axial load-bending moment capacity of the specimens under different loading conditions. Moreover, theoretical equations based on the confinement pressure of transverse reinforcement provide accurate predictions of the theoretical load-carrying capacity of the columns reinforced with GFRP bars and helices.
\end{abstract}

\section{Keywords}

Ambient-cured, Columns, Geopolymer concrete, GFRP, Loading conditions 


\section{loading conditions}

Muhammad N. S. Hadi ${ }^{1}$; Shehroze $\mathrm{Ali}^{2}$; and M. Neaz Sheikh ${ }^{3}$

${ }^{1}$ Associate Professor, School of Civil, Mining, and Environmental Engineering, University of Wollongong, Australia,mhadi@uow.edu.au (Corresponding author)

${ }^{2}$ Ph.D. Candidate, School of Civil, Mining, and Environmental Engineering, University of Wollongong, Australia,sa217@uowmail.edu.au

${ }^{3}$ Associate Professor, School of Civil, Mining, and Environmental Engineering, University of Wollongong, Australia, msheikh@uow.edu.au

\section{Abstract}

This study discusses the behavior of ambient-cured circular geopolymer concrete specimens tested under different loading conditions. Twelve specimens were cast and tested to investigate the influence of the type of the reinforcement, that is, steel and glass fiberreinforced polymer (GFRP), pitch of the transverse reinforcement and loading conditions (concentric axial load, 15 and $35 \mathrm{~mm}$ eccentric load, and four-point bending). The axial load carrying capacity, confinement efficiency and deformability of the specimens decreased for the replacement of the steel reinforcement with the same amount of GFRP reinforcement under concentric and eccentric loads. However, the deformability of the GFRP reinforced concrete (RC) specimen was higher than the deformability of its steel counterpart specimen under four-point bending. Overall, the reduction in the pitch of the GFRP helices in the GFRP-RC specimens resulted in a significant improvement in the confinement efficiency, deformability, post-peak behavior and the axial load-bending moment capacity of the specimens under different loading conditions. Moreover, theoretical equations based on the confinement pressure of transverse reinforcement provide accurate predictions of the theoretical load carrying capacity of the columns reinforced with GFRP bars and helices. 
26 Keywords: Geopolymer concrete; ambient-cured; columns; glass fiber-reinforced polymer

27 (GFRP); loading conditions

\section{Introduction}

29 Concrete is widely used as an important construction material for the development of 30 infrastructure, with an estimated yearly consumption of 30 billion tonnes (Monteiro et al. 31 2017). The use of ordinary Portland cement (OPC) as a binder material in concrete is a 32 traditional method to produce concrete. Therefore, the production of a huge volume of OPC 33 is a substantial industrial activity, which contributes to $5-7 \%$ of $\mathrm{CO}_{2}$ in the overall 34 greenhouse gas emissions (Miller et al. 2016).

35 Geopolymer concrete is a new form of concrete produced with aluminosilicate binders

36 rather than the cement binder. The production of geopolymer concrete involves a process of geopolymerization of industrial waste materials that are rich in alumina and silica (Davidovits 1991). The synthesis of commercially available binders, i.e., ground granulated blast furnace slag (GGBFS) and fly ash (FA), is carried out in the presence of an alkaline solution (sodiumhydroxide and sodium silicate). The studies reported that the production of geopolymer based pastes and concrete significantly reduced greenhouse gas emissions (McLellan et al. 2011; Turner et al. 2013; Nawaz et al. 2020). Several research studies indicated that geopolymer concrete is a durable construction material with mechanical properties as good as the OPC concrete. However, some of the challenges in the use of geopolymer concrete include the need for special handling, high cost of alkaline solutions and loss of uniformity of the mix. Although geopolymer concrete lacks in ductility, it offers higher fire resistance with low susceptibility to shrinkage and creep than OPC concrete. In addition, geopolymer concrete possesses comparable or even higher chemical resistance against chloride and sulphate attacks compared to OPC concrete (Sofi et al. 2007; Duxson et al. 2007; Kong and Sanjayan 
2010). It is found that heat curing significantly improves the compressive strength of

51 geopolymer concrete at an early age (Sindhunata et al. 2006). However, heat curing restricts

52 the use of geopolymer concrete for precast structural members. The development of ambient-

53 cured geopolymer concrete is a major breakthrough in the use of geopolymer concrete, as it

54 offers economical solution and simplification for in-situ constructions (Hadi et al. 2017;

55 Ahmad et al. 2021a).

56 The service life of reinforced concrete $(\mathrm{RC})$ structures is currently a major concern of the

57 construction industry. One of the main factors affecting the performance of RC structures is

58 the corrosion and degradation of steel reinforcement. Therefore, the use of fiber-reinforced

59 polymer (FRP) bars instead of conventional steel bars has become an innovative solution,

60 particularly for marine structures (Hadi et al. 2020; Ali et al. 2021; Ahmad et al. 2021b). The

61 FRP bars are lightweight (20-25\% of the density of steel), corrosion resistant, and non-

62 electromagnetic. In addition, FRP bars have high tensile strength and fatigue resistance

63 compared to the conventional steel bars, making FRP bars suitable alternatives to steel bars in

64 RC structures (Cheng and Karbhari 2006).

65 A number of studies investigated the shear and the flexural behavior of OPC and 66 geopolymer concrete structural members reinforced with FRP composites (Barris et al. 2009;

67 El-Nemr et al. 2013; Maranan et al. 2018; Maranan et al. 2019). The FRP bars have lower 68 compressive strength compared to their tensile strength (Afifi et al. 2014). The American

69 Concrete Institute guide ACI 440.1R-15 (ACI 2015) provides no guidelines for the use of the 70 longitudinal FRP bars in compression members. The Canadian Standards CSA S806-12:R17

71 (CSA 2017) ignores the contribution of FRP bars in compression. However, the recent

72 Canadian highway bridge design code CSA S6-19 (CSA 2019) permits to account the 73 contribution of FRP bars in compression. 
The behavior of columns reinforced with FRP bars has also been investigated. Alsayed et al. (1999) investigated the behavior of rectangular RC columns for the replacement of steel reinforcement with the glass fiber-reinforced polymer (GFRP) reinforcement. It was found that the axial load carrying capacity of GFRP-RC columns was $13 \%$ lower than that of the steel-RC columns. Choo et al. (2006) reported that neglecting the contribution of FRP bars under compression was a conservative approach. Tobbi et al. (2012) found that the contribution of GFRP bars in the axial load carrying capacity of the columns was about $10 \%$. Hadhood et al. (2017) considered the contribution of GFRP bars under compression in the section analysis and developed load-moment characteristics of eccentrically loaded circular concrete columns reinforced with GFRP bars and helices, which reasonably agreed with the experimental results. Further, it was found that the use of the GFRP longitudinal reinforcement ratio up to $3.3 \%$ enhanced the stiffness of the columns (Hadhood et al. 2018). The deformability and the post-peak load-deformation behavior of the GFRP-RC columns improved significantly for the reduction in the pitch of the GFRP helices (Pantelides et al. 2013, Hadi et al. 2016, Hasan et al. 2017). Guérin et al. (2018) reported that the level of the axial load eccentricity significantly influenced the strength, failure mode and overall behavior of the GFRP-RC columns. The effect of slenderness ratio of GFRP-RC columns under concentric and eccentric loads was investigated in Abdelazim et al. (2020). The study recommended limiting the maximum slenderness ratio to 18 for short GFRP-RC columns. Elmesalami et al. (2021) investigated the behavior of FRP-RC columns under concentric and eccentric loads. It was found that the effect of reinforcement ratio on the load carrying capacity is more pronounced on the eccentrically loaded columns as compared to the concentrically loaded columns. columns. Sumajouw et al. (2007) tested twelve geopolymer concrete columns of $175 \times 175$ 
$99 \mathrm{~mm}$ cross-section and $1500 \mathrm{~mm}$ height reinforced with steel bars. The test results of the study

100 agreed with the theoretical results calculated using the design provisions of Australian

101 Standard AS 3600-01 (AS 2001) and American design code ACI 318-02 (ACI 2002). Sarker

102 (2009) found that the analysis of steel-RC geopolymer concrete columns can be performed

103 using the analytical method for OPC concrete columns with the appropriate stress-strain

104 relationship of the geopolymer concrete. Farhan et al. (2018a) tested sixteen circular steel-RC

105 geopolymer concrete columns under axial and flexural loads. It was found that the

106 deformability of the columns increased significantly with the addition of steel fibers.

107 In comparison with Aramid-FRP (AFRP) and Carbon-FRP (CFRP), Glass-FRP (GFRP)

108 bars possess better mechanical characteristics, and they are economical and more desirable in

109 the construction industry ( $\mathrm{Hu}$ et al. 2020). A detailed review of the literature reveals that

110 GFRP bars and geopolymer concrete are suitable materials for columns, particularly for

111 marine structures and structures that require electromagnetic transparency. The use of GFRP

112 bars leads to an overall reduction in the weight of the structure. The combination of GFRP

113 bars and geopolymer concrete is an excellent option that can be used as an alternative of steel

114 bars and OPC concrete for the columns. Maranan et al. (2016) investigated the behavior of

115 ambient-cured circular geopolymer concrete columns reinforced with GFRP bars. However,

116 the experimental testing presented in Maranan et al. (2016) was limited to the concentrically

117 loaded columns. In reality, construction errors and moving loads can cause eccentric and

118 flexural loads in the columns. In fact, most columns are exposed to a combination of axial

119 loading and bending moment. Hence, this study investigates the effect of the concentric axial

120 load, 15 and $35 \mathrm{~mm}$ eccentric loads and flexural load on the behavior of ambient-cured

121 circular geopolymer concrete columns reinforced with GFRP bars and helices. The

122 eccentricity to height ratio was 0.023 and 0.055 for 15 and $35 \mathrm{~mm}$ eccentrically loaded

123 specimens, respectively. In addition, the effect of replacing steel reinforcement with the same 
124 amount of GFRP reinforcement, the pitch of GFRP helices and the loading condition were

125 investigated. Moreover, the theoretical axial load carrying capacities of the columns were

126 calculated using various confinement based prediction equations proposed in the literature.

\section{Experimental program}

\section{Details of the test matrix}

129 The experimental program comprised testing of twelve ambient-cured circular geopolymer

130 concrete column specimens. The specimens were distributed into three groups with four

131 specimens in each group based on the type and the arrangement of the reinforcement. Three

132 specimens in each group were of $160 \mathrm{~mm}$ diameter and $640 \mathrm{~mm}$ height. The fourth specimen

133 in each group was of $160 \mathrm{~mm}$ diameter and $1500 \mathrm{~mm}$ height. The first group (S40) included

134 the specimens reinforced longitudinally with six N10 (diameter $=10 \mathrm{~mm}$ ) deformed steel

135 bars and transversely with R8 (diameter $=8 \mathrm{~mm}$ ) plain steel helices with $40 \mathrm{~mm}$ pitch. The

136 second and third groups (G40, G75) included the specimens reinforced longitudinally with

137 six G10 (diameter $=10 \mathrm{~mm}$ ) GFRP bars. The specimens in the second and the third groups

138 were reinforced transversely with G8 (diameter $=8 \mathrm{~mm}$ ) GFRP helices with $40 \mathrm{~mm}$ and 75

$139 \mathrm{~mm}$ pitch, respectively. The specimens in the first group (S40) were used as reference

140 specimens. The specimens in the second group (G40) were prepared to study the influence of

141 the type of reinforcement (steel and GFRP) on the behavior of circular geopolymer concrete

142 columns. The specimens in the third group (G75) were prepared to investigate the effect of

143 increasing the pitch of the transverse GFRP helices on the behavior of ambient-cured circular

144 geopolymer concrete columns. The dimensions of the column specimens tested under

145 concentric and eccentric loading were chosen to be suitable to the condition and capacity of

146 the available testing equipment in the laboratory. In addition, the vertical support with $l / h$

147 ratio greater than or equal to 2.5 is considered as a short column according to the provisions 
148 of the Canadian codes CSA S806-12:R17 (CSA 2017) and CSA S6-19 (CSA 2019). The

149 design of the helical reinforcement for the tested GFRP-RC specimens meets the minimum

150 bar diameter, pitch and volumetric ratio of FRP helical reinforcement requirements outlined

151 in CSA S806-12:R17 (CSA 2017). It is noted that the experimental program was designed

152 before the release of CSA S6-19 (CSA 2019).

153 Table 1 shows the test matrix used in this study. The dimensions and reinforcement details

154 of the specimens are presented in Fig. 1. The first specimen of each group was tested under

155 concentric axial load. The second and the third specimens of each group were tested under 15

156 and $35 \mathrm{~mm}$ eccentric loads, respectively. The axial load eccentricities of $15 \mathrm{~mm}(e / D=0.09)$

157 and $35 \mathrm{~mm}(e / D=0.22)$ were selected considering the diameter of the columns and the

158 available test facility in the structural engineering laboratory at the University of

159 Wollongong, Australia. The letters " $e$ " and " $D$ " refer to the loading eccentricity and diameter

160 of the specimen, respectively. The lower bound of the load eccentricity $(e / D=0.09)$ was

161 taken approximately half of the upper bound eccentricity $(e / D=0.22)$. The fourth specimen

162 of each group was tested as a beam under four-point bending to investigate the pure flexural

163 behavior of the specimens. The size $(D \times H=160 \times 1500 \mathrm{~mm})$ of the specimens tested under

164 four-point bending was selected to minimize the effect of shear induced deflection at mid 165 span.

166 The specimens were identified by specimen labels. Each label consists of letters and

167 numbers based on the type of reinforcement, arrangement of the transverse helices and

168 loading conditions (Table 1). The first part of each label represents the reinforcement 169 material, where "S" and "G" refer to steel and GFRP reinforcement, respectively. Afterwards,

170 the second part of each label refers to the pitch of the helices. The numbers 40 and 75

171 represent $40 \mathrm{~mm}$ and $75 \mathrm{~mm}$ pitch, respectively. The third part represents the loading

172 condition, i.e., E0 refers to concentric axial load, E15 and E35 refer to 15 and $35 \mathrm{~mm}$ 
173 eccentric loads, respectively, and B refers to four-point bending. For example, Specimen

174 G40E35 represents the geopolymer concrete specimen reinforced longitudinally with 6G10

175 bars and transversely with GFRP helices at $40 \mathrm{~mm}$ pitch and tested under $35 \mathrm{~mm}$ eccentric

176 load.

177 Materials and mix proportions of geopolymer concrete

178 All the specimens were cast using geopolymer concrete with a design compressive strength

179 of

$18050 \mathrm{MPa}$ at 28 days. The geopolymer concrete mix was prepared using ground granulated

181 blast furnace slag (GGBFS), fly ash (FA), alkaline solution, coarse aggregate (up to $10 \mathrm{~mm}$ 182 size), fine aggregates (river sand), water and superplasticizer. The GGBFS and FA were 183 supplied by the local suppliers (ASA 2019; BORAL 2019). The alkaline solution of 14 184 molarity was prepared by mixing sodium hydroxide $(\mathrm{NaOH})$ and sodium silicate $\left(\mathrm{Na}_{2} \mathrm{SiO}_{3}\right)$ 185 solutions. The $\mathrm{Na}_{2} \mathrm{SiO}_{3}$ solution was composed of $\mathrm{Na}_{2} \mathrm{O}=14.7 \%$ and $\mathrm{SiO}_{2}=29.4 \%$ with a 186 modulus ratio (Ms) of $2\left(\mathrm{SiO}_{2} / \mathrm{Na}_{2} \mathrm{O}\right)$, as per the manufacturer (PQ 2019). Locally available superplasticizer (Viscocrete-10) was used to enhance the workability of the fresh geopolymer concrete mix (Sika 2019). The mix proportions used in this study were similar to those

189 proposed in a previous study conducted by Ali et al. (2019) for ambient-cured geopolymer 190 concrete (Table 2). In Ali et al. (2019), trial mixes were prepared and tested to modify the 191 mix design of Hadi et al. (2017) for desired workability and compressive strength.

\section{Preliminary testing}

193 The preliminary testing included the chemical analysis of GGBFS and FA, the tensile and 194 compressive strength of steel and GFRP reinforcement and the compressive strength of 195 ambient cured geopolymer concrete. The chemical composition of GGBFS and FA was 196 determined using X-Ray Fluorescent (XRF) test. The GGBFS contained $42.7 \%$ calcium 
oxide $(\mathrm{CaO})$ by mass and the FA contained $83.4 \%$ of alumino-silicates $\left(\mathrm{Al}_{2} \mathrm{O}_{3} \cdot \mathrm{SiO}_{2}\right)$ by mass.

198 The fly ash was classified as Class F in accordance with ASTM C618-19 (ASTM 2019). The

199 test results of the chemical analysis of GGBFS and FA are presented in Table 3.

200 The mechanical properties of both N10 and R8 straight steel bars were determined in 201 accordance with AS 1391-17 (AS 2017). The yield tensile strength and elastic tensile 202 modulus of N10 deformed steel bars were $552 \mathrm{MPa}$ and $193 \mathrm{GPa}$, respectively. The yield 203 tensile strength and elastic tensile modulus of R8 plain steel bars were $520 \mathrm{MPa}$ and 190 $204 \mathrm{GPa}$, respectively. The surface of the GFRP bars was ribbed for an effective bonding between 205 the bars and the surrounding concrete. The root diameters of G10 and G8 GFRP bars were $2069.2 \mathrm{~mm}$ and $7.4 \mathrm{~mm}$, respectively, as per the specifications provided by the manufacturer 207 (Pultron 2019). The root diameter of the GFRP bars refers to the diameter of an unprojected 208 surface between the ribs. The diameter of G10 and G8 GFRP bars obtained using the 209 immersion test was $9.8 \mathrm{~mm}$ and $7.7 \mathrm{~mm}$, in accordance with ISO 10406-1-15 (ISO 2015).

210 The mechanical properties of both G10 and G8 straight GFRP bars were determined based on 211 the root diameters in accordance with ASTM D7205-16 (ASTM 2016) and ASTM D695-15 212 (ASTM 2015). The tensile strength and elastic tensile modulus of G10 GFRP bars were 1263 $213 \mathrm{MPa}$ and $63.8 \mathrm{GPa}$, respectively. The tensile strength and elastic tensile modulus of straight

214 G8 GFRP bars were $1162 \mathrm{MPa}$ and $61.9 \mathrm{GPa}$, respectively. The compressive strengths of 215 G10 and G8 GFRP bar specimens were determined using the slenderness ratios of 16:1 and 216 13:1, respectively. The slenderness ratios of the tested GFRP bar specimens were within the 217 permissible range specified in ASTM D695-15 (ASTM 2015). The compressive strengths of $218 \mathrm{G} 10$ and G8 GFRP bars were $827 \mathrm{MPa}$ and $907 \mathrm{MPa}$, respectively. Table 4 shows the 219 average properties of steel and GFRP reinforcement. The typical tensile stress-strain behavior 220 of steel and GFRP longitudinal bars are presented in Fig. 2. Figure $3 \mathrm{a}$ and $3 \mathrm{~b}$ show the GFRP 221 bars and GFRP helices used in this study. 
The compressive strength of ambient-cured geopolymer concrete was determined by

224 2014) and the average compressive strengths are reported. The average compressive strengths

225 of ambient-cured geopolymer concrete at 7 days and 28 days were $35 \mathrm{MPa}$ and $52 \mathrm{MPa}$,

226 respectively. In addition, the compressive strength of geopolymer concrete on the day of 227 testing for each specimen was also determined. The average compressive strength of 228 geopolymer concrete on the day of testing was $54.4 \mathrm{MPa}$.

\section{$229 \quad$ Fabrication and casting of specimens}

230 All the specimens were fabricated and cast as per the design of each specimen. The

231 longitudinal steel and GFRP bars were aligned in the vertical position by using two wooden

232 circular templates having an outer diameter of $112 \mathrm{~mm}$. Each template contained six uniformly distributed holes around the diameter to hold the longitudinal bars in place. One additional hole at the center of each template was used to hold a fixed threaded steel rod as per the required height of the specimens. Afterwards, the longitudinal reinforcement was assembled with the transverse reinforcement using steel wire ties of $150 \mathrm{~mm}$ length. The helices were positioned using aluminum spacer jigs to attain $40 \mathrm{~mm}$ and $75 \mathrm{~mm}$ pitch for the specimens of different groups (Fig. 3c).

239 Electrical strain gauges were attached to the longitudinal bars and helices to obtain strain 240 readings during the test (Fig. 3d). The longitudinal bars were attached with $25 \mathrm{~mm}$ steel pins

241 at the bottom to maintain a uniform concrete cover of $25 \mathrm{~mm}$ at the ends of all the specimens.

242 The steel and GFRP reinforcement cages were assembled to attain an outer diameter of 128 mm (Fig. 3e). The steel wires were attached to the reinforcement cages to maintain the concrete cover $(16 \mathrm{~mm})$ at the sides of the specimens. Afterwards, the steel and the GFRP reinforcement cages were placed inside the molds. Polyvinyl chloride (PVC) pipes with an 
internal diameter of $160 \mathrm{~mm}$ were used to cast the specimens. All PVC molds were placed on

247 a flat wooden pallet to avoid unnecessary movements.

248 The mixing of the geopolymer concrete started with the mixing of the coarse aggregate 249 and fine aggregate for 1 minute. The binders (slag and fly ash) were then added into the 250 mixer and mixed for two minutes. Once the dry materials were mixed, the alkaline solution 251 was slowly added into the mixer, followed by the water and the superplasticizer. The mixing continued for another 3-4 minutes and a homogenous mixture of geopolymer concrete was prepared. The fresh mix of the geopolymer concrete was directly poured into the PVC molds. Based on the capacity of the pan mixer, three batches were prepared to fill the molds for the specimens of each group (S40, G40, and G75). The specimens were poured in three layers and each layer was compacted using an electric vibrator to remove the entrapped air.

257 Afterwards, all the specimens were kept under ambient-curing conditions until the testing 258 day.

\section{Testing setup and instrumentation}

260 All concentrically and eccentrically loaded specimens were tested using a $5000-k N$ Denison compression testing machine. The top and the bottom ends of the concentric and eccentric loaded specimens were externally wrapped with two layers of carbon fiber-reinforced polymer (CFRP) sheet of $80 \mathrm{~mm}$ width and $0.5 \mathrm{~mm}$ thickness to avoid any premature failure

264 during the testing due to the stress concentration at the ends. In addition, both ends of the specimens were capped with plaster to ensure a uniform distribution of load across the section during the test. A pair of loading heads were fabricated and used at the top and the bottom of the specimens to apply axial loads with the required eccentricity. The loading heads were composed of circular steel plates and steel ball joints. The inner diameter of each circular steel plate was greater than the diameter of the tested specimen. The gap between the 
inner wall of the loading head and the specimen was filled with a $3 \mathrm{~mm}$ thick layer of plaster

271 to confine the end region of the specimen. All concentrically loaded specimens were tested

272 without using steel ball joints in the loading heads. Therefore, the specimens experienced 273 concentric axial load directly from the testing machine through the circular steel plates. On

274 the other hand, for the specimens tested under eccentric load, the steel ball joints were used to transfer the eccentric load from the testing machine at $15 \mathrm{~mm}$ eccentricity and $35 \mathrm{~mm}$ eccentricity. A similar test setup was adopted in Farhan et al. (2018b). Figure 4a shows the test setup for the specimens tested under eccentric loads.

The specimens tested as beams under four-point bending were tested using a $1000-k N$ loading frame. Two circular steel rigs were used at the top and the bottom of the beam specimens to transfer the load from the testing machine. The inner diameter of each steel rig was equal to the diameter of the tested specimen. All the specimens under four-point bending were tested over a clear span of $1300 \mathrm{~mm}$. The spacing between the two point loads was 433.3

mm. Figure $4 \mathrm{~b}$ shows the test setup for the specimens tested as beams under four-point bending.

286 The behavior of the test specimens was monitored through electrical strain gauges, linear variable displacement transducers (LVDTs) and laser triangulation. Two strain gauges were attached to the two opposite outermost longitudinal bars in the plane of bending at the midheight of the specimens to observe the strains in the longitudinal reinforcement. In addition, two strain gauges were attached to the helices $\left(180^{\circ}\right.$ apart) at the mid-height of the specimens to observe the strain development in the transverse reinforcement. All strain gauges were positioned on the reinforcement at the mid-height of the test region. Two LVDTs were attached vertically on the opposite corners in the plane of bending between the loading head and the supporting head of the Denison compression-testing machine to measure the axial 
295 deformation in the specimens tested under concentric and eccentric loads. The lateral 296 deformation of the specimens tested under the eccentric load was recorded by a laser 297 triangulation attached at the mid-height of the tested specimen. The midspan deflection of the 298 specimens tested as beams in the loading frame was recorded by a laser triangulation placed 299 under the midspan of the tested specimens, as shown in Fig. 4b.

300 The testing began by applying force-controlled loads on the specimens up to $10 \%$ of their 301 predicted load carrying capacity at a rate of $2 \mathrm{kN} / \mathrm{s}$. Then the specimens were unloaded to 20

$302 \mathrm{kN}$ at the same rate. This process was adopted to prevent any movement that might have 303 taken place during the test. Afterwards, the loading continued under the displacement-control

304 system at a rate of $0.18 \mathrm{~mm} / \mathrm{min}$ for the specimens tested in the Denison compression testing 305 machine. A loading rate of $0.96 \mathrm{~mm} / \mathrm{min}$ was used for the specimens tested as beams under 306 four-point bending in the loading frame. All the specimens were tested until the failure of the 307 specimen. The internal load cell of the testing machines (5000-kN Denison testing machine 308 and 1000-kN loading frame) recorded the test results. The strain gauges, LVDTs and the laser 309 triangulations were attached to a data logger to record the testing data at every 2 s. Two 310 computers were attached to store the test results: one from the internal load cell of the 311 individual testing machine and the other from the data logger.

\section{Experimental results and discussions}

\section{Behavior of specimens tested under concentric axial load}

314 Three specimens (one from each group) were tested under concentric axial load. The failure 315 modes of the column specimens tested under concentric axial loads are shown in Fig. 5. The

316 failure modes of the tested specimens under concentric axial loads were mainly influenced by

317 the type of reinforcement (steel or GFRP) and the arrangement of the transverse helices. All 318 specimens were tested to failure. 
319 The failure of Specimens S40E0, G40E0 and G75E0 occurred in the following 320 mechanism. With an increase in the axial load, the longitudinal strain increased. Also, lateral 321 expansion was observed in the geopolymer concrete due to Poisson's effect, which could be 322 due to little or no contribution to the confinement of concrete core provided by helices. At

323 the peak concentric axial load, the lateral expansion resulted in the formation of vertical 324 hairline cracks at the mid-height of the tested specimens. In Specimen G75E0, wider and 325 deeper cracks were observed as compared to Specimens S40E0 and G40E0. This could be 326 due to the increased pitch of the helices in Specimen G75E0 compared to Specimens S40E0 327 and G40E0. After the peak axial load, the spalling of the concrete cover occurred, causing the 328 formation of progressive cracks and an increase in the lateral expansion of the geopolymer concrete core. The total failure of Specimen S40E0 occurred due to the extensive buckling of the longitudinal steel bars and rupture of the steel helix (Fig. 6a.). Similar observations were

331 reported for concrete columns in Pantelides et al. (2013). However, in Specimen G40E0, 332 closely spaced GFRP helices resisted the lateral movement of the longitudinal GFRP bars.

333 This led to the kinking of the glass fibers in the longitudinal GFRP bars, which was followed 334 by the delamination and fracture of the longitudinal GFRP bars on the tension side, crushing 335 of concrete core and the rupture of the GFRP helices (Fig. 6b). On the other hand, in 336 Specimen G75E0, widely spaced GFRP helices provided less confinement, which resulted in 337 the buckling and rupture of the longitudinal GFRP bars, as shown in Fig. 6c.

338 The experimental results of the specimens tested under concentric axial load are presented 339 in Table 5. The load capacities are normalized against the compressive strength of 340 geopolymer concrete on the day of testing, using Eq. (1).

$$
P^{*}=\frac{P}{f_{c o} A_{g}}
$$


341 where $P^{*}$ refers to the normalized load capacity. The $f_{c o}$ and $A_{g}$ are the compressive 342 strength of geopolymer concrete on the day of testing and gross area of the specimen, 343 respectively. The $f_{c o}$ values for all the specimens are provided in Table 6. The normalized 344 axial load-axial deformation behaviors of the concentrically loaded Specimens S40E0, 345 G40E0 and G75E0 are shown in Fig. 7. It can be observed that the ascending slope of the 346 curve of Specimen G75E0 was slightly lower than the ascending slope of the curve of 347 Specimen G40E0, although the difference is not significant. The slight variation could be 348 because of the non-homogeneity of the geopolymer concrete caused during mixing, placing 349 and compaction, which might have affected the properties of geopolymer concrete. Neville 350 (2011) reported similar observations for OPC concrete. It can also be observed that 351 Specimens S40E0, G40E0 and G75E0 followed a linear ascending path until the peak load 352 because of the low lateral expansion of the geopolymer concrete due to little or no contribution to the confinement of concrete core provided by helices. This could be because the Poisson's ratio of geopolymer concrete is less than the Poisson's ratio of normal strength OPC concrete (Hardjito 2005). Also, geopolymer concrete is more brittle than OPC concrete. Afterwards, a short non-linear reduced slope before the peak load represents the crushing and cracking of the geopolymer concrete. In general, at $95 \%$ of the peak load, hairline cracks started to appear at the mid-height surface of the specimens due to the lateral expansion of the geopolymer concrete. The confinement provided by the helices was partially activated at this

360 stage. Later on, the cracks widened and formed major vertical cracks, followed by the 361 complete spalling of the concrete cover. This led to complete activation of the transverse 362 reinforcement, which provided confinement and resisted the lateral movement of the geopolymer concrete core. As a result, a slight increase in the post-peak behavior was observed, followed by the failure of reinforcement. 
The replacement of steel reinforcement (in Specimens S40E0) directly with the same amount of GFRP reinforcement (in Specimens G40E0) resulted in an approximately 27\% reduction in the normalized axial load carrying capacity. On the other hand, Specimen G40E0 sustained about 10\% higher peak normalized load than Specimen G75E0. This was because of the reduction in the pitch of the GFRP helices from $75 \mathrm{~mm}$ to $40 \mathrm{~mm}$. Karim et al. (2016) reported similar observations for circular concrete columns reinforced with GFRP bars and helices. After the peak axial load, all the specimens experienced a drop in the axial load caused by the spalling of the concrete cover, which initiated the lateral expansion of the geopolymer concrete core. Specimen S40E0 experienced a drop of about $49 \%$ in the peak normalized axial load before the rupture of the steel helix. The corresponding axial deformation in Specimen S40E0 before the rupture of steel helix was recorded as $17.9 \mathrm{~mm}$. On the other hand, Specimens G40E0 and G75E0 experienced about 25\% and $41 \%$ loss of their peak normalized axial loads, respectively, before the rupture of the GFRP reinforcement. The rupture of the GFRP helices in Specimens G40E0 and G75E0 occurred at axial deformations of $7.3 \mathrm{~mm}$ and $6.4 \mathrm{~mm}$, respectively.

380 The contribution of longitudinal bars in compression $\left(P_{b a r}\right)$ is also presented in Table 5. In the reference Specimen S40E0, the value of $P_{b a r}$ was calculated by multiplying the nominal area of the longitudinal steel bars with the yield strength of the steel bar. The axial load contribution of GFRP bars was calculated by multiplying the nominal area of the longitudinal GFRP bar with the measured average strain in the longitudinal bars and the modulus of elasticity of the longitudinal bars. In Specimen S40E0, the axial load contribution of longitudinal steel bars in the peak normalized axial load was approximately $21 \%$. On the other hand, the average axial load contribution of GFRP bars in Specimens G40E0 and G75E0 was approximately $6 \%$. This could be due to the brittle nature of GFRP bars compared to steel bars. 
391 Six specimens (two from each group) were tested under the eccentric load. Specimens 392 S40E15, G40E15 and G75E15 were tested under $15 \mathrm{~mm}$ eccentric load and Specimens 393 S40E35, G40E35 and G75E35 were tested under $35 \mathrm{~mm}$ eccentric load. The failure modes of 394 the specimens tested under 15 and $35 \mathrm{~mm}$ eccentric loads are shown in Fig. 5.

395 The failure of the eccentrically loaded specimens initiated with the crushing of the 396 geopolymer concrete cover on the compression face. The crushing of the geopolymer 397 concrete cover on the compression face initiated the transverse cracking on the tension face.

398 This behavior was because of the combined axial-flexural load. It was observed that the 399 width and the depth of the cracks on the tension side increased with an increase in the axial 400 loading and were dependent on the pitch of the helices. The specimens reinforced with 401 widely spaced helices experienced deeper cracks as compared to the specimens reinforced 402 with closely spaced helices. Afterwards, Specimens S40E15 and S40E35 experienced 403 buckling of the longitudinal steel bars on the compression side. The total failure of 404 Specimens S40E15 and S40E35 occurred due to the extensive buckling of the longitudinal 405 steel bars on the compression side and rupture of the longitudinal steel bars on the tension 406 side, as shown in Fig. 6d. After the completion of the test, the remaining intact concrete cover 407 was removed to inspect the failure of the reinforcement. Similar observations were reported 408 for geopolymer concrete columns reinforced with steel bars and helices in Farhan et al. 409 (2018a). On the other hand, in Specimens G40E15 and G75E15, the longitudinal GFRP bars 410 fractured at the mid-height on the compression side of the specimen, causing the failure of the 411 specimens. Specimens G40E35 and G75E35 experienced flexural-tension failure caused by 412 spalling of the concrete cover on the compression side followed by the rupture of the GFRP 413 bars at the upper third portion of the tension side of the specimens (Fig. 5). 
414 The experimental test results of the specimens tested under 15 and $35 \mathrm{~mm}$ eccentric loads

415 are presented in Table 7. Figure 8a shows the normalized axial load-axial deformation and 416 normalized axial load-lateral deformation behavior of the specimens tested under $15 \mathrm{~mm}$

417 eccentric load. It can be observed that the ascending part of the normalized axial load-axial

418 deformation curves of steel and GFRP-RC specimens were almost linear until the peak axial 419 load.

420 The peak normalized axial load sustained by Specimens G40E15 and G75E15 were about $421 \quad 18 \%$ and $31 \%$, respectively, lower than the peak normalized axial load sustained by reference 422 Specimen S40E15. After the peak axial load, the concrete cover started to spall off on the 423 compression side, which activated the transverse reinforcement. In comparison with the 424 concentrically loaded specimens, the specimens of Groups S40, G40 and G75 experienced $42531 \%, 22 \%$ and $28 \%$ reduction, respectively, in the normalized load carrying capacities for the 426 increase in the loading eccentricity from zero to $15 \mathrm{~mm}$.

427 Figure $8 \mathrm{~b}$ shows the normalized axial load-axial deformation and normalized axial load428 lateral deformation behavior of the specimens tested under $35 \mathrm{~mm}$ eccentric load. The 429 behavior of Specimens S40E35, G40E35 and G75E35 in the ascending part of the normalized 430 axial load-axial deformation curve was almost linear until the peak normalized axial load. 431 Specimens G40E35 and G75E35 sustained 16\% and 29\% lower peak normalized axial load, 432 respectively, than the reference Specimen S40E35. In comparison with the concentrically 433 loaded specimens, the specimens of Groups S40, G40 and G75 sustained $64 \%, 58 \%$ and $61 \%$ 434 lower peak normalized axial load, respectively, by increasing the eccentricity of the axial 435 load from zero to $35 \mathrm{~mm}$. It was also observed that Specimens G75E15 and G75E35 436 sustained lower peak axial loads compared to Specimens G40E15 and G40E35 due to the 437 lower confinement pressure provided by the transverse reinforcement. 
439 Three specimens (one from each group) were tested as beams under four-point bending to 440 investigate the behavior of the geopolymer concrete specimens under flexural load. Figure 9

441 presents the failure mode of the geopolymer concrete specimens tested under four-point 442 bending.

443 The failure of the specimens tested as beams under four-point bending initiated with the 444 formation of hairline cracks at the midspan on the tension side. This was followed by the 445 crushing of concrete in the compression region at the midspan of the specimens. The width 446 and number of the cracks on the tension side varied depending upon the pitch of the helices in 447 the specimens. The specimens reinforced with closely spaced helices (S40B and G40B) 448 experienced closely spaced hairline cracks. However, the specimen reinforced with widely spaced helices (G75B) exhibited wide but deep cracks. Similar observations were reported in Hasan et al. (2017). The crushing of concrete on the mid-span compression side resulted in an increase in the deflection of the specimens, which led to the development of new cracks as well as increased the depth of the existing cracks on the tension side. At this stage, the

453 flexural load of the specimens was dropped to $80 \%$. Afterwards, the flexural load continued to drop until the rupture of the reinforcing bars on the tension side, which led to the ultimate failure of the specimens. The rupture of the longitudinal steel bars in the extreme tension side at the midspan led to the total failure of Specimen S40B. On the other hand, the rupture of both GFRP bars and GFRP helices on the tension side at the midspan resulted in the complete failure of Specimens G40B and G75B.

The experimental test results of steel and GFRP-RC specimens tested as beams under 460 four-point bending are presented in Table 8. Figure 10 shows the normalized load-midspan 461 deflection behavior of the specimens tested under four-point bending. It can be observed that 462 all the specimens showed an ascending behavior until the first peak load. The initial cracking 
in Specimens S40B, G40B and G75B started at almost same normalized load. The reference

464 Specimen S40B showed only one peak load. On the other hand, Specimens G40B and G75B 465 continued to resist the flexural loads beyond the first peak loads and achieved the second 466 peak loads. The normalized loads sustained by Specimens G40B and G75B at the first peaks 467 were approximately $12 \%$ and $17 \%$ less, respectively, compared to the reference Specimen 468 S40B. The midspan deflections of Specimens G40B and G75B at the first peak load were approximately $46 \%$ and $60 \%$ higher, respectively, than the midspan deflection of Specimen S40B. Afterwards, a drop in the flexural loads was observed due to the crushing of the geopolymer concrete cover on the compression face.

In the post-peak zone, Specimens G40B and G75B showed ascending post-peak behavior until the second peak load due to the high tensile strength and the elastic stress-strain relationship of GFRP bars and GFRP helices. The second peak normalized loads of Specimens G40B and G75B were about 27\% and 13\% higher, respectively, compared to their first peak loads. Afterwards, all the specimens experienced crushing of the concrete cover on the compression face, followed by a drop in the load. In general, Specimen G40B sustained approximately $12 \%$ and $19 \%$ higher normalized load than Specimens S40B and G75B, respectively.

\section{Confinement Efficiency and Deformability}

481 In this study, the experimental confinement efficiency and deformability of the specimens 482 were determined to investigate the influence of the type of reinforcement (steel or GFRP) and the arrangement of reinforcement. The procedure for determining the confinement efficiency and deformability was based on the recommendations suggested in Afifi et al. (2014) and

485 Hadi et al. (2016), respectively. The experimental confinement efficiency of the column 486 specimens was calculated as the ratio of the compressive strength of the confined geopolymer 
concrete column to the compressive strength of the unconfined geopolymer concrete column

$488\left(f^{\prime}{ }_{c c} / f_{c o}\right)$. The $f^{\prime}{ }_{c c}$ represents the maximum stress sustained by the area of the confined 489 geopolymer concrete core. On the other hand, the $f_{c o}$ is equivalent to $0.85 f^{\prime}{ }_{c}$. The area of the 490 confined geopolymer concrete core was measured based on the outside to outside diameter of 491 the helices. A similar approach was adopted in Pantelides et al. (2013) for the calculation of 492 the area of the confined concrete core. The deformability of the specimens was computed as 493 the area under the axial load-axial deformation curve up to the ultimate deformation divided 494 by the area of the axial load-axial deformation curve up to the deformation at the end of the 495 linear elastic stage. The ultimate deformation represents the smaller of the first fracture load 496 of the reinforcement and $80 \%$ of the peak load, as adopted in Hadi et al. (2016). The point 497 where the first crack occurred or the ascending branch of the load-deformation curve started 498 flattening prior to the peak load was considered as the end of the linear elastic stage for all the 499 specimens. The load and deformation values recorded at the end of the linear elastic stage of 500 the concentrically and eccentrically loaded specimens are presented in Table 5 and Table 7 , 501 respectively. Table 6 shows the values of the confinement efficiency and deformability of the 502 specimens.

503 The direct replacement of steel reinforcement by the same amount of GFRP reinforcement 504 resulted in an approximately $28 \%$ reduction in the confinement efficiency in Specimen 505 G40E0 compared to the confinement efficiency in Specimen S40E0. The confinement 506 efficiency of Specimen G40E15 was approximately 19\% less than that of Specimen S40E15. 507 Specimen G40E35 achieved approximately 7\% less confinement efficiency than that of 508 Specimen S40E35. In GFRP-RC specimens, the reduction in the pitch of GFRP helices from $50975 \mathrm{~mm}$ to $40 \mathrm{~mm}$ resulted in the improvement in confinement efficiency. Thus, Specimen 510 G40E0 achieved about 5\% higher confinement efficiency than that of Specimen G75E0. The 511 confinement efficiency of Specimen G40E15 was about 17\% higher compared to Specimen 
512 G75E15. The confinement efficiency of Specimen G40E35 was 28\% higher than the 513 confinement efficiency of Specimen G75E35.

514 Figure 11a shows the effect of loading eccentricity on the confinement efficiency of the

515 specimens. It was observed that the confinement efficiency of the specimens decreased with

516 an increase in the loading eccentricity from zero to 15 and $35 \mathrm{~mm}$ (Fig. 11a). The 517 confinement efficiency of Specimens S40E15 and S40E35 were about 32\% and 64\% less, 518 respectively, compared to the confinement efficiency of Specimen S40E0. Similarly, the 519 confinement efficiency of Specimens G40E15 and G40E35 were about 23\% and 53\% less, 520 respectively, compared to the confinement efficiency of Specimen G40E0. The confinement 521 efficiency of Specimens G75E15 and G75E35 were about 31\% and 62\% less, respectively, compared to the confinement efficiency of Specimen G75E0.

Figure $11 \mathrm{~b}$ shows the deformability of the specimens tested under different loading conditions. It can be observed that the deformability of GFRP-RC Specimen G40E0 was approximately $42 \%$ less than the deformability of steel-RC Specimen S40E0. The deformability of Specimens G40E15 and G40E35 were approximately 4\% and 8\% less, respectively, compared to the deformability of Specimens S40E15 and S40E35. Overall, the specimens with closely spaced GFRP helices, experienced effective confinement, which resisted the lateral movement of the geopolymer concrete core in the specimens. Specimen

530 G40E0 achieved about 14\% higher deformability than Specimen G75E0. The deformability 531 of Specimen G40E15 was approximately 15\% higher than the deformability of Specimen

532 G75E15. Specimen G40E35 achieved 25\% higher deformability than Specimens G75E35.

533 Figure $11 \mathrm{~b}$ also shows that the increase in the loading eccentricity from zero to 15 and 35 $534 \mathrm{~mm}$ resulted in the reduction of deformability for all the steel and the GFRP-RC geopolymer 535 concrete specimens. The deformability of eccentrically loaded steel-RC Specimens S40E15 536 and S40E35 were about $43 \%$ and $45 \%$, respectively, lower than the deformability of the 
concentrically loaded Specimen S40E0. The deformability of eccentrically loaded GFRP-RC Specimens G40E15 and G40E35 were approximately 5\% and 11\%, respectively, lower than the deformability of the concentrically loaded Specimen G40E0. Similarly, the deformability 540 of Specimens G75E15 and G75E35 were about $6 \%$ and 20\%, respectively, lower than the 541 deformability of Specimen G75E0.

542 Unlike the concentric and eccentric loaded specimens, the deformability of the GFRP-RC specimen tested under four-point bending was significantly higher than the deformability of

544 the counterpart steel bar reinforced specimen, as shown in Fig. 11b. This could be because of 545 the higher tensile strength of GFRP bars compared to the equivalent steel bars (Table 4).

546 Therefore, the contribution of GFRP bars was higher than the steel bars in resisting the

547 flexural load. Thus, the deformability of Specimen G40B was approximately $31 \%$ higher than 548 the deformability of Specimen S40B. In GFRP-RC specimens, the reduction in the pitch of 549 the GFRP helices increased the deformability. Specimen G40B achieved 15\% higher 550 deformability than Specimen G75B. Similar observations were reported for the GFRP-RC 551 specimens in Hadi et al. (2017).

\section{Experimental axial load-bending moment interaction diagrams}

553 The experimental axial load-bending moment $(P-M)$ interaction diagrams plotted for the 554 specimens of Groups S40, G40 and G75 were based on four points. In the $(P-M)$ interaction 555 diagram, the first point represents the concentrically loaded specimens. The second and third 556 points represent the $15 \mathrm{~mm}$ and $35 \mathrm{~mm}$ eccentrically loaded specimens, respectively. The 557 fourth point represents the pure bending moment capacity of the specimen tested as a beam 558 under four-point bending. For the specimens tested under concentric axial load, the bending 559 moment was considered to be zero. For the specimens tested under $15 \mathrm{~mm}$ and $35 \mathrm{~mm}$ 560 eccentric axial loads, the experimental bending moment capacity $(M)$ at the mid-height was 
calculated using Eq. (2). The experimental bending moment capacity $(M)$ of the specimens

562 tested as beams under four-point bending was calculated using Eq. (3).

$$
\begin{gathered}
M=\text { Ppeak }(e+\delta) \\
M=\frac{\text { Ppeak } 1 \times L}{6}
\end{gathered}
$$

563 where; $P_{\text {peak }}=$ the peak axial load, $e=$ the load eccentricity, and $\delta=$ the lateral deformation of

564 the specimen corresponding to the peak axial load, $P_{\text {peakl }}=$ the first peak flexural load, and $L$ $565=$

566 the length $(1300 \mathrm{~mm})$ between the end supports of the beam specimens.

567 The experimental results of the flexurally loaded specimens are presented in Table 9 and 568 the experimental $(P-M)$ interaction diagrams are shown in Fig. 12. It can be observed that the 569 load-bending moment capacity of the steel-RC specimens of Group S40 under concentric axial load, eccentric axial load and four-point bending were higher than the GFRP-RC specimens of Group G40. This could be because of the high modulus of elasticity of the steel bars compared to the GFRP bars. On the other hand, the load bending moment capacity of the specimens of Group G40 was significantly higher compared to the load-bending moment capacity of the specimens of Group G75.

\section{Experimental versus predicted load capacity of concentrically loaded specimens}

576 The American design code ACI 318-19 (ACI 2019) recommends Eq. (3) to predict the axial

577 load capacity of OPC concrete columns reinforced with the steel reinforcement. However, 578 considering the lower compressive strength of FRP bars compared to their tensile strength, 579 ACI 440.1R-15 (ACI 2015) does not recommend the use of FRP bars for the longitudinal 580 reinforcement of concrete columns. In fact, ACI 440.1R-15 (ACI 2015) provides no design 581 guidelines for the longitudinal reinforcement of concrete columns with FRP bars. The 
582 Canadian standard CSA S806-12:R17 (CSA 2017) permits the use of FRP bars for the

583 longitudinal reinforcement of concrete columns but neglects the contribution of FRP bars in 584 the axial load carrying capacity of FRP bar RC columns. Based on CSA S806-12:R17 (CSA 585 2017), Eq. (4) can be used to predict the axial load capacity of FRP bar RC columns.

$$
\begin{aligned}
& P_{o}=0.85 f_{c}^{\prime}\left(A_{g}-A_{s t}\right)+f_{y} A_{s t} \\
& P_{o}=\alpha f_{c}^{\prime}\left(A_{g}-A_{f}\right) ; \quad \alpha=0.85-0.0015 f_{c}^{\prime} \geq 0.67
\end{aligned}
$$

586 where $P_{o}$ is the theoretical axial load carrying capacity, $f_{c}^{\prime}$ is the 28-day unconfined 587 compressive

588 strength of concrete; $A_{g}, A_{s t}$ and $A_{f}$ are the gross area of the column, area of steel bars and area of FRP bars, respectively.

590 A number of studies reported that neglecting the contribution of longitudinal FRP bar in compression (as presented in Eq. 5) underestimated the axial load carrying capacity of FRPRC columns (Tobi et al. 2012; Afifi et al. 2014; Hadi et al. 2016). Therefore, in the literature, two different approaches were adopted to account for the contribution of longitudinal FRP

594 bars in the axial load carrying capacity of the columns. In the first approach, Afifi et al. 595 (2014) calculated the stress in FRP bars by using the tensile strength of the FRP bars, as 596 shown in Eq. 6.

$$
P_{o}=0.85 f_{c}^{\prime}\left(A_{g}-A_{f}\right)+\alpha_{f} f_{f u} A_{f}
$$

597 where $\alpha_{f}$ is a reduction factor to account the decrease in the compressive strength of GFRP 598 bar as a function of the tensile strength of GFRP bar. The value of $\alpha_{f}$ was recommended to be 599 assumed as 0.35 in Afifi et al. (2014). In Eq. (4), $f_{f u}$ represents the ultimate tensile strength of 600 the longitudinal FRP bar in tension.

601 In the second approach, the stress in the FRP bars was calculated using the axial strain $\left(\varepsilon_{f}\right)$ 602 in the FRP bars and the modulus of elasticity $\left(E_{f}\right)$ of the FRP bars, as shown in Eq. (7). 


$$
P_{o}=0.85 f_{c}^{\prime}\left(A_{g}-A_{f}\right)+\varepsilon_{f} E_{f} A_{f}
$$

603 Mohamed et al. (2014) used Eq. (7) to calculate $P_{o}$ of the FRP-RC columns by including the

604 FRP strength contribution until the development of micro-cracks in the concrete plastic stage.

605 In Mohamed et al. (2014), the $\varepsilon_{f}$ value was assumed as 0.002 corresponding to the initiation 606 of plastic concrete deformation. Similarly, Hadi et al. (2016) and Hadhood et al. (2017) used

607 Eq. (7) to calculate the $P_{o}$ for the FRP-RC columns. However, in Hadi et al. (2016) and 608 Hadhood et al. (2017), $\varepsilon_{f}$ was taken as 0.003. Further, Hadhood et al. (2017) also used the 609 modified factors $k_{1}=0.85-0.0015 f^{\prime}{ }_{c}$ and $k_{2}=0.0035$ in Eq. (7) and provided reasonable 610 predictions for the $P_{o}$ of the FRP-RC columns. It is noted that the recent Canadian highway 611 bridge design code CSA S6-19 (CSA 2019) considers the contribution of the compressive 612 strength of FRP bars by limiting the stress corresponding to a strain of 0.002 in the 613 calculation of the axial load carrying capacity of FRP bar RC columns.

614 In this study, it was observed that the change in the pitch of the GFRP helices affected the 615 confinement stress, which altered the axial load carrying capacities of the columns. Similar 616 observations were reported by Pantelides et al. (2013), Karim et al. (2016), Maranan et al. 617 (2016) and Hadhood et al. (2018). Thus, considering Eq. (7), $f^{\prime}{ }_{c}$ was replaced with $f^{\prime}{ }_{c c}$ 618 (ultimate confined concrete strength) to include the effect of confinement in the theoretical 619 axial load carrying capacity of the concentrically loaded GFRP-RC column specimens, as 620 shown in Eq. (8).

$$
P_{o}=0.85 f_{c c}^{\prime}\left(A_{g}-A_{f}\right)+\varepsilon_{f} E_{f} A_{f}
$$

621 The value of $f^{\prime}{ }_{c c}$ was calculated based on the lateral confining pressure $\left(f_{I F R P}\right)$ provided by 622 the GFRP helices, using different prediction equations, including Pantelides et al. (2013), 623 Karim et al. (2016), Maranan et al. (2016) and Hadhood et al. (2018), as shown in Table 10 624 Among the available equations for confined concrete strength $\left(f_{c c}^{\prime}\right)$ and lateral confining 
625 pressure $\left(f_{l F R P}\right)$, the equations proposed in Maranan et al. (2016) were developed to 626 investigate especially the behavior of GFRP-RC geopolymer columns (Table 10). The 627 predicted values of $P_{o}$ were calculated using $\varepsilon_{f}=0.003$ in the longitudinal GFRP bars.

628 Table 11 presents a comparison between the normalized experimental and theoretical axial 629 load carrying capacities of all the concentrically loaded geopolymer concrete columns. The $630 P_{o} / P_{\text {exp. }}$ refer to the ratio of the predicted load to the experimental load carrying capacity of 631 the columns. It can be observed that, as expected, based on ACI 318-19 (ACI 2019), Eq. (2) 632 reasonably predicts the $P_{o}$ of steel bar reinforced geopolymer concrete column specimen with $633 P_{o} / P_{\text {exp. }}$ of 0.94 . The $P_{o}$ of the concentrically loaded GFRP-RC column calculated using 634 CSA S806-12:R17 (CSA 2017) and CSA S6-19 (CSA 2019) underestimated the axial load 635 capacity of the specimen with $P_{o} / P_{\text {exp. }}$ of 0.77 and 0.82 , respectively. The approaches 636 adopted in Mohammed et al. (2014), Hadi et al. (2016) and Hadhood et al. (2017) predicted 637 the $P_{o}$ for the concentrically loaded GFRP-RC column with $P_{o} / P_{\text {exp. }}$ ranged between 0.85 638 0.93. The approach adopted by Afifi et al. (2014) overestimated the axial load carrying 639 capacity of the GFRP-RC column with $P_{o} / P_{\text {exp. }}$ of 1.02.

640 It was also observed that, to consider the effect of the confinement, the prediction 641 equations proposed in Pantelides et al. (2013), Karim et al. (2016), Maranan et al. (2016) and 642 Hadhood et al. (2018) provided a good correlation between the experimental and theoretical $643 P_{o}$ of all the GFRP-RC columns. Pantelides et al. (2013) provided accurate predictions for all 644 the GFRP-RC column specimens with $P_{o} / P_{\text {exp. }}$ ranging $0.97-0.99$. Based on Karim et al. 645 (2016) and Maranan et al. (2016), the $P_{o} / P_{\text {exp. }}$ for all GFRP-RC columns ranged $0.93-0.99$ 646 and $0.75-0.86$, respectively. The predictions based on Hadhood et al. (2018) for all GFRP647 RC columns ranged between $0.85-0.90$. Hence, the prediction equations proposed by 648 Pantelides et al. (2013) and Hadi et al. (2016) and Hadhood et al. (2018) can be used for the 649 precise predictions of the $P_{o}$ for the geopolymer concrete columns reinforced with GFRP bars 
and GFRP helices. Also, the contribution of longitudinal GFRP bars should not be neglected

651 and need to be taken into account in predicting the axial load capacity of FRP bar reinforced

652 geopolymer concrete columns.

\section{Conclusions}

654 This study investigated the behavior of ambient cured geopolymer concrete circular column

655 specimens under different loading conditions. The effect of replacing steel reinforcement 656 with the same amount of GFRP reinforcement was investigated. Based on the experimental 657 results, the following conclusions are drawn:

658 1. The failure of the steel RC specimens initiated with the buckling of the longitudinal steel 659 bars and then rupture of the longitudinal steel bar or fracture of steel helix, which caused a 660 complete failure of the specimens. On the other hand, the failure of the GFRP-RC 661 specimens initiated with the kinking of glass fibers in GFRP bars. The complete failure of 662 the specimens occurred due to the rupture of the longitudinal GFRP bars and GFRP 663 helices.

664 2. Replacing the steel reinforcement with the same amount of GFRP reinforcement in the 665 geopolymer concrete column specimens resulted in the reduction of the normalized axial 666 load carrying capacity by $27 \%, 18 \%$ and $16 \%$ tested under concentric, $15 \mathrm{~mm}$ eccentric 667 and $35 \mathrm{~mm}$ eccentric loads, respectively.

668 3. The replacement of steel reinforcement with the same amount of GFRP reinforcement in 669 the geopolymer concrete column specimens resulted in the reduction of the deformability 670 by $42 \%, 4 \%$ and $8 \%$ under concentric, $15 \mathrm{~mm}$ eccentric and $35 \mathrm{~mm}$ eccentric loads, 671 respectively.

672 4. Reducing the pitch of the GFRP helices from $75 \mathrm{~mm}$ to $40 \mathrm{~mm}$ improved the normalized 673 load carrying capacity by $10 \%, 19 \%$ and $19 \%$ for specimens tested under concentric, 15 
$674 \mathrm{~mm}$ eccentric and $35 \mathrm{~mm}$ eccentric loads, respectively. The improvement in the 675 deformability due to the reduction in the pitch of the GFRP helices was $5 \%, 17 \%$ and $28 \%$

676 for specimens tested under concentric, $15 \mathrm{~mm}$ eccentric and $35 \mathrm{~mm}$ eccentric loads, 677 respectively.

678 5. The contribution of the longitudinal GFRP bars was on average $6 \%$ in the axial load 679 carrying capacity of the GFRP-RC specimens.

680 6. Under four-point bending, all GFRP-RC specimens achieved second peak axial loads, 681 unlike the steel bar reinforced specimen. For the same pitch of the helices, GFRP-RC 682 specimen achieved approximately $12 \%$ and $31 \%$ higher flexural load and deformability, 683 respectively, compared to its steel bar reinforced counterpart specimen.

684 7. The theoretical axial load carrying capacity of the geopolymer concrete columns 685 reinforced with GFRP bars and GFRP helices can be reasonably predicted by considering 686 the contribution of the longitudinal FRP bars and the effect of the FRP confinement 687 provided by the helices.

688 Based on the results of this study, it can be concluded that GFRP reinforcement is a 689 promising material that can be used for reinforcing circular geopolymer concrete columns.

690 The above conclusions were drawn based on the experimental study conducted on twelve 691 circular geopolymer concrete columns tested under different loading conditions. Considering 692 that the size of the tested concentrically and eccentrically loaded specimens is small, further 693 research investigations are required on full-scale GFRP-RC geopolymer concrete columns for 694 their wide practical applications.

695 Data Availability Statement

696 All data used during the study appear in the submitted article.

\section{Acknowledgments}


698 The authors wish to acknowledge the support of the technical officers of High-Bay laboratory

699 in the University of Wollongong, Australia, especially Mr. Fernando Escribano, Mr. Duncan

700 Best and Mr. Ritchie McLean in conducting the experimental work of this research. The

701 authors are also thankful to the Australasian Slag Association and the Boral group of

702 Companies, Wollongong, Australia for providing Ground granulated blast furnace slag and

703 Fly ash, respectively. In addition, the authors would like to thank Mr. Ian Cumming of

704 MateenBar Australia for providing GFRP bars and helices for the experimental work of this

705 study. Further, the second author would like to acknowledge the Higher Education

706 Commission Pakistan and the University of Wollongong for providing $\mathrm{PhD}$ scholarship. In

707 addition, the second author would like to thank his family members for their support.

\section{$708 \quad$ References}

709 Abdelazim, W., H. M. Mohamed, and B. Benmokrane. 2020. "Inelastic second-order analysis

710 for slender GFRP-reinforced concrete columns: Experimental investigations and

711 theoretical study." J. Compos. Constr. 24(3): 04020016.

712 ACI (American Concrete Institute). 2002. Building Code Requirements for Structural 713 Concrete and Commentary. ACI 318-02. Farmington Hills, MI: ACI.

714 ACI (American Concrete Institute). 2015. Guide for the design and construction of structural 715 concrete reinforced with FRP bars. ACI 440.1R-15. Farmington Hills, MI: ACI.

716 ACI (American Concrete Institute). 2019. Building Code Requirements for Structural 717 Concrete and Commentary. ACI 318-19. Farmington Hills, MI: ACI.

718 Afifi, M. Z., H. M. Mohamed, and B. Benmokrane. 2014. "Axial capacity of circular 719 concrete

720 columns reinforced with GFRP bars and spirals.” J. Compos. Constr. 18 (1). 04013017. 
721 Ahmad, J., T. Yu, and M. N. S. Hadi. 2021a. "Behavior of GFRP bar reinforced 722 geopolymer concrete filled GFRP tube columns under different loading 723 conditions.” Struct. 33: 1633-1644.

724 Ahmad, J., T. Yu, and M. N. S. Hadi. 2021b. "Basalt Fiber-Reinforced Polymer-Confined 725 Geopolymer Concrete.” ACI Struct. J. 118(1): 289-300.

726 Ali, S., M. N. Sheikh, M. Sargeant, and M. N. S. Hadi. 2019. "Influence of polypropylene 727 and glass fibers on AASF concrete.” ACI Struct. J. 117 (4): 183-192.

728 Ali, S., M. N. Sheikh, and M. N. S. Hadi. 2021 "Behavior of axially loaded plain and 729 fiber reinforced geopolymer concrete columns with glass fiber reinforced polymer $730 \quad$ cages." Struct. Concr. 1-17.

731 Alsayed, S. H., Y. A. Al-Salloum, T. H. Almusallam, and M. A. Amjad. 1999. "Concrete 732 columns reinforced by glass fiber reinforced polymer rods." Proc., 4th Int. Sym. on Fiber 733 Reinforced Polymer Reinforcement for Reinforced Concrete Structures (ACI 1999). 734 Farmington Hills (MI, USA). p. 103-112.

735 AS (Australian Standard). 2001. Concrete Structures. AS 3600-01. Sydney, Australia: AS. 736 AS (Australian Standard). 2014. Methods of testing concrete- Method 9: Determination of the 737 compressive strength of concrete specimens. AS 1012.9-14. Sydney, Australia: AS.

738 AS (Australian Standard). 2017. Standard for metallic materials- Tensile testing at ambient 739 temperature. AS 1391-2017. Sydney, Australia: AS.

740 ASA (Australasian Slag Association). 2019. Accessed May 5, 2019. http://www.asa$741 \quad$ inc.org.au/products/granulated-blast-furnace-slag.

742 ASTM (American Society for Testing and Materials). 2015. Standard test method for 743 compressive properties of rigid plastics. ASTM D695-15. West Conshohocken, PA. $744 \quad$ ASTM. 
ASTM (American Society for Testing and Materials). 2016. Standard test method for tensile

746 properties of fiber reinforced polymer matrix composite bars. ASTM D7205-16. West

747 Conshohocken, PA. ASTM.

748 ASTM (American Society for Testing and Materials). 2019. Standard specification for coal

$749 \quad$ fly ash and raw or calcined natural pozzolan for use as a mineral admixture in portland 750 cement concrete. ASTM C618-19. West Conshohocken, PA. ASTM.

751 Barris, C., LI. Torres, A. Turon, M. Baena, and A. Catalan. 2009. “An experimental study of 752 the flexural behaviour of GFRP RC beams and comparison with prediction models."

753 Compos. Struct. 91 (3): 286-295.

754 BORAL Australia. 2019. Accessed May 5, 2019, https:/www.boral.com.au/products/ $755 \quad$ cementitious/ fly-ash-products.

756 Cheng, L., and V. M. Karbhari. 2006. "New bridge systems using FRP composites and $757 \quad$ concrete

Choo, C. C., I. E. Harik, and H. Gesund. 2006. "Strength of rectangular concrete columns reinforced with fiber-reinforced polymer bars.” ACI Struct. J. 103 (May/Jun): 452-459.

CSA (Canadian Standard Association). R2017. Design and Construction of Building Components with Fiber Reinforced Polymers. CSA S806-12. Rexdale, Canada.

CSA (Canadian Standard Association). 2019. Canadian Highway Bridge Design code. CSA 764 S6-19. Rexdale, Canada.

765 Davidovits, J. 1991. “Geopolymers.” J. Therm. Anal. Calorim. 37 (8): 1633-1656.

766 Duxson, P., J. L. Provis, G. C. Lukey, and J. S. J. Van Deventer. 2007. "The role of inorganic 767 polymer technology in the development of 'green concrete'." Cem. Concr. Res. 37 (12): $768 \quad 1590-1597$. 
El-Nemr, A., E. A. Ahmed, and B. Benmokrane. 2013. "Flexural Behavior and Serviceability of Normal-and High-Strength Concrete Beams Reinforced with Glass Fiber-Reinforced Polymer Bars. ACI Struct. J. 110 (6): 1077-1087.

Elmesalami, N., F. Abed, and A.E. Refai. 2021. "Concrete Columns Reinforced with GFRP and BFRP Bars under Concentric and Eccentric Loads: Experimental Testing and Analytical Investigation.” J. Compos. Constr., 25(2): 04021003.

Farhan, N. A., M. N. Sheikh, and M. N. S. Hadi. 2018. "Behaviour of Ambient Cured Steel Fibre Reinforced Geopolymer Concrete Columns Under Axial and Flexural Loads.” Struct. 15 (Aug): 184-195.

778

Farhan, N. A., M. N. Sheikh, and M. N. S. Hadi. 2018. "Behavior of Ambient-Cured 779 Geopolymer Concrete Columns under Different Loads.” ACI Struct. J. 115(5): 1419-1429.

Guérin, M., H. M. Mohamed, B. Benmokrane, A. Nanni, and C. K. Shield, 2018. "Eccentric Behavior of Full-Scale Reinforced Concrete Columns with Glass Fiber-Reinforced Polymer Bars and Ties.” ACI Struct. J., 115(2): 489-499.

Hadhood, A., H. M. Mohamed, and, B. Benmokrane, 2017. "Failure envelope of circular 784 concrete columns reinforced with glass fiber-reinforced polymer bars and spirals." $A C I$ Struct. J. 114(6): 1417-1428.

786

Hadhood, A., H. M. Mohamed, F. Ghrib, and B. Benmokrane. 2017. "Efficiency of glassfiber reinforced-polymer (GFRP) discrete hoops and bars in concrete columns under combined axial and flexural loads." Compos. B. Eng. 114(Apr): 223-236.

789 Hadhood, A., H. M. Mohamed, and B. Benmokrane. 2018. "Flexural stiffness of GFRP-and 790 CFRP-RC circular members under eccentric loads based on experimental and curvature analysis." ACI Struct. J. 115(4): 1185-1198. 
Hadi, M. N. S., J. Ahmad, and T. Yu. 2020. "Investigation of BFRP bar reinforced geopolymer concrete filled BFRP tube columns.” Proc. Inst. Civil. Eng-Struct. Build. 116.

Hadi, M. N. S, and J. Youssef. 2016. "Experimental investigation of GFRP-reinforced and GFRP-encased square concrete specimens under axial and eccentric load, and four-point bending test." J. Compos. Constr. 20 (5). 04016020.

Hadi, M. N. S., H. Karim, and M. N. Sheikh. 2016. "Experimental investigations on circular concrete columns reinforced with GFRP bars and helices under different loading conditions.” J. Compos. Constr. 20 (4). 04016009.

Hadi, M. N. S., N. A. Farhan, and M. N. Sheikh. 2017. "Design of geopolymer concrete with GGBFS at ambient curing condition using Taguchi method." Constr. Build. Mater. 140 (Jun): 424-431.

Hadi, M. N. S, H. A. Hasan, and M. N. Sheikh. 2017. "Experimental investigation of circular high-strength concrete columns reinforced with glass fiber-reinforced polymer bars and helices under different loading conditions.” J. Compos. Constr. 21 (4). 04017005.

Hardjito, D. 2005. "Studies of fly ash-based geopolymer concrete." Curtin University, Australia.

Hasan, H. A., M. N. Sheikh, and M. N. S. Hadi. 2017. "Performance evaluation of high strength concrete and steel fibre high strength concrete columns reinforced with GFRP bars and

813 Hu, W., Y. Li, and H. Yuan, 2020. "Review of Experimental Studies on Application of FRP 814 for Strengthening of Bridge Structures.” Adv. Mater. Sci. Eng. 8682163. 
815 ISO (International Organization for Standardization). 2015. Fiber-reinforced polymer (FRP)

816 reinforcement of concrete: Test Methods: Part 1: FRP bars and grids. IS0 10406-1-15.

$817 \quad$ Switzerland.

818 Karim, H., M. N. Sheikh, and M. N. S. Hadi. 2016. "Axial load-axial deformation behaviour

819 of circular concrete columns reinforced with GFRP bars and helices." Constr. Build. $820 \quad$ Mater. 112 (Jun): 1147-1157.

821 Maranan, G. B., A. C. Manalo, B. Benmokrane, W. Karunasena, and P. Mendis. 2016.

822 "Behavior of concentrically loaded geopolymer-concrete circular columns reinforced 823 longitudinally and transversely with GFRP bars.” Eng. Struct. 117 (Jun) : 422-436.

824 Maranan, G. B., A. C. Manalo, B. Benmokrane, W. Karunasena, P. Mendis, and T. Q. 825 Nguyen. 2018. "Shear behaviour of geopolymer-concrete beams transversely reinforced 826 with continuous rectangular GFRP composite spirals." Compos. Struct. 187 (Mar): 454827465.

828 Maranan, G. B., A. C. Manalo, B. Benmokrane, W. Karunasena, P. Mendis, and T. Q. 829 Nguyen. 2019. "Flexural behavior of geopolymer-concrete beams longitudinally 830 reinforced with GFRP and steel hybrid reinforcements.” Eng. Struct. 182: 141-152.

831 Mohamed, H. M., M. Z. Afifi, and B. Benmokrane 2014. "Performance evaluation of 832 concrete columns reinforced longitudinally with FRP bars and confined with FRP hoops 833 and spirals under axial load.” J. Bridge. Eng. 19(7). 04014020.

834 McLellan, B. C., R. P. Williams, J. Lay, A. V. Riessen, and G. D. Corder. 2011. "Costs and 835 carbon emissions for geopolymer pastes in comparison to ordinary Portland cement." $J$. $836 \quad$ Clean. Prod. 19 (9-10): 1080-1090.

837 Miller, S. A., P. J. M. Monteiro, C. P. Ostertag and A. Horvath. 2016. "Comparison indices 838 for 
839 design and proportioning of concrete mixtures taking environmental impacts into 840 account." Cem. Concr. Compos. 68 (Apr): 131-143.

841 Monteiro, P. J., S. A. Miller and A. Horvath. 2017. "Towards sustainable concrete." Nat. 842 mater. 16 (7): 698-699.

843 Nawaz, M., A. Heitor and M. Sivakumar. 2020. "Geopolymers in construction-recent 844 developments." Constr. Build. Mater. 260: 120472.

845 Neville, A. M. 2011. Properties of concrete: Fourth and final edition. Essex, U.K.

846 Pantelides, C. P., M. E. Gibbons, and L. D. Reaveley. 2013. "Axial load behavior of $847 \quad$ concrete

848 columns confined with GFRP spirals.” J. Compos. Constr. 17 (3): 305-313.

849 PQ Australia Limited. 2019. "Data Sheet: D ${ }^{\mathrm{TM}}$ Sodium Silicate Solution.” Accessed July 25, 850 2019. https://www. pqcorp.com/products/sodium-silicate-liquids/d.

851 Pultron. 2019. "Technical data sheet: mateenbar ${ }^{\mathrm{TM}}$ composite reinforcement bar for concrete 852 structures.” Accessed May 11, 2019. http://www.mateenbar.com/product-and-technical853 information.

854 Kong, D. L. and J. G. Sanjayan. 2010. "Effect of elevated temperatures on geopolymer paste, 855 mortar and concrete." Cem. Concr. Res. 40(2): 334-339.

856 Sarker, P. K. 2009. “Analysis of geopolymer concrete columns.” Mater. Struct. 42 (6): 715$857 \quad 724$.

858 Sika Australia. 2019. "Data sheet: Sika ViscoCrete-10 PDS.” Accessed March 15, 2019. 859 https://aus.sika.com.

860 Sindhunata, J. S. J. Van Deventer, G.C. Lukey, and H. Xu. 2006. "Effect of curing 861 temperature and silicate concentration on fly-ash-based geopolymerization." Ind. Eng. $862 \quad$ Chem. Res. 45(10): 3559-3568. 
863 Sofi, M., J. S. J. Van Deventer, P. A. Mendis, and G. C. Lukey. 2007. "Engineering 864 properties of inorganic polymer concretes (IPCs)." Cem. Concr. Res. 37 (2): 251-257.

865 Sumajouw, D. M. J., D. Hardjito, S. E. Wallah, and B. V. Rangan. 2007. "Fly ash-based 866 geopolymer concrete: study of slender reinforced columns.” J. Mater. Sci. 42 (9): 3124$867 \quad 3130$.

868 Tobbi, H., A. S. Farghaly, and B. Benmokrane. 2012. "Concrete Columns Reinforced 869 Longitudinally and Transversally with Glass Fiber-Reinforced Polymer Bars." ACI Struct. $870 \quad$ J. 109 (4): 551-558.

871 Turner, L. K., and F. G. Collins. 2013. "Carbon dioxide equivalent $\left(\mathrm{CO}_{2}\right.$-e) emissions: A 872 comparison between geopolymer and OPC cement concrete." Constr. Build. Mater. 43 873 (Jun): 125-130. 
Table 1. Test matrix.

\begin{tabular}{|c|c|c|c|c|}
\hline Group & Specimen & $\begin{array}{l}\text { Longitudinal } \\
\text { reinforcement }\end{array}$ & $\begin{array}{c}\text { Transverse } \\
\text { reinforcement }\end{array}$ & $\begin{array}{c}\text { Axial Load } \\
\text { eccentricity }(\mathrm{mm})\end{array}$ \\
\hline \multirow{4}{*}{$\mathrm{S} 40$} & S40E0 & \multirow{4}{*}{ Steel 6N10 } & \multirow{4}{*}{ Steel R8@40mm } & 0 \\
\hline & $\mathrm{S} 40 \mathrm{E} 15$ & & & 15 \\
\hline & S40E35 & & & 35 \\
\hline & S40B & & & Flexural \\
\hline \multirow{4}{*}{ G40 } & G40E0 & \multirow{4}{*}{ GFRP 6G10 } & \multirow{4}{*}{ GFRPG8@40mm } & 0 \\
\hline & G40E15 & & & 15 \\
\hline & G40E35 & & & 35 \\
\hline & G40B & & & Flexural \\
\hline \multirow{4}{*}{ G75 } & G75E0 & \multirow{4}{*}{ GFRP 6G10 } & \multirow{4}{*}{ GFRP G8@75 mm } & 0 \\
\hline & G75E15 & & & 15 \\
\hline & G75E35 & & & 35 \\
\hline & G75B & & & Flexural \\
\hline
\end{tabular}

Table 2. Mix proportions of the geopolymer concrete (Based on Ali et al. 2019)

\begin{tabular}{|c|c|c|c|c|c|c|c|c|c|c|c|}
\hline \multicolumn{3}{|l|}{ Material } & \multicolumn{2}{|c|}{ Quantity } & & & & & & & \\
\hline \multicolumn{3}{|l|}{ FA $\left(\mathrm{kg} / \mathrm{m}^{3}\right)$} & \multicolumn{2}{|c|}{270} & & & & & & & \\
\hline \multicolumn{3}{|c|}{ GGBFS $\left(\mathrm{kg} / \mathrm{m}^{3}\right)$} & \multicolumn{2}{|c|}{180} & & & & & & & \\
\hline \multicolumn{3}{|c|}{ Aggregate $\left(\mathrm{kg} / \mathrm{m}^{3}\right)$} & \multicolumn{2}{|c|}{1295} & & & & & & & \\
\hline \multicolumn{3}{|c|}{ Sand $\left(\mathrm{kg} / \mathrm{m}^{3}\right)$} & \multicolumn{2}{|c|}{552} & & & & & & & \\
\hline \multicolumn{3}{|c|}{$\mathrm{Na}_{2} \mathrm{SiO}_{3}\left(\mathrm{~kg} / \mathrm{m}^{3}\right)$} & \multicolumn{2}{|c|}{112.5} & & & & & & & \\
\hline \multicolumn{3}{|c|}{$\mathrm{NaOH}\left(\mathrm{kg} / \mathrm{m}^{3}\right)$} & \multicolumn{2}{|c|}{45} & & & & & & & \\
\hline \multicolumn{3}{|c|}{$\mathrm{NaOH}($ mole/l) } & \multicolumn{2}{|c|}{14} & & & & & & & \\
\hline \multicolumn{3}{|l|}{$\mathrm{Al} / \mathrm{Bi}^{\mathrm{a}}$} & \multicolumn{2}{|c|}{0.35} & & & & & & & \\
\hline \multicolumn{3}{|c|}{$\mathrm{Na}_{2} \mathrm{SiO}_{3} / \mathrm{NaOH}$} & \multicolumn{2}{|c|}{2.5} & & & & & & & \\
\hline \multicolumn{3}{|c|}{ Superplasticizer $\left(\mathrm{kg} / \mathrm{m}^{3}\right)$} & \multicolumn{2}{|c|}{34.7} & & & & & & & \\
\hline \multicolumn{3}{|c|}{ Water $\left(\mathrm{kg} / \mathrm{m}^{3}\right)$} & \multicolumn{2}{|c|}{86.4} & & & & & & & \\
\hline \multicolumn{12}{|c|}{${ }^{\mathrm{a}} \mathrm{Al} / \mathrm{Bi}=$ alkaline activator to binder mass ratio. } \\
\hline \multicolumn{12}{|c|}{$\begin{array}{l}\text { Table 3. Chemical composition (mass \%) of ground granulated blast furnace slag (GGBFS } \\
\text { and fly ash (FA). }\end{array}$} \\
\hline \multirow{2}{*}{ Material } & \multicolumn{11}{|c|}{ Components } \\
\hline & $\mathrm{CaO}$ & $\mathrm{Al}_{2} \mathrm{O}_{3}$ & $\mathrm{SiO}_{2}$ & $\mathrm{MgO}$ & $\mathrm{Fe}_{2} \mathrm{O}_{3}$ & $\mathrm{~K}_{2} \mathrm{O}$ & $\mathrm{Na}_{2} \mathrm{O}$ & $\mathrm{TiO}_{2}$ & $\mathrm{P}_{2} \mathrm{O}_{5}$ & $\mathrm{Mn}_{2} \mathrm{O}_{3}$ & $\mathrm{SO}_{3}$ \\
\hline GGBFS & 42.7 & 12.8 & 34.5 & 5.3 & 0.4 & 0.3 & 0.8 & 0.8 & 0.1 & 0.4 & 1.7 \\
\hline FA & 2.9 & 26.2 & 62.4 & 0.4 & 2.6 & 1.1 & 0.6 & 0.9 & 0.2 & 0.1 & 0.3 \\
\hline
\end{tabular}

Note: Loss on ignition for GGBFS and FA were $0.1 \%$ and $2.0 \%$ by mass, respectively. 
Table 4. Average properties of the bars.

\begin{tabular}{lcccc}
\hline Average properties of the bars & R8 (Steel) & N10 (Steel) & G8 (GFRP) & G10 (GFRP) \\
\hline Nominal diameter $(\mathrm{mm})$ & 8 & 10 & $8\left(7.7^{\mathrm{a}}, 7.4^{\mathrm{b}}\right)$ & $10\left(9.8^{\mathrm{a}}, 9.2^{\mathrm{b}}\right)$ \\
Tensile strength $(\mathrm{MPa})$ & $520^{\mathrm{c}}$ & $552^{\mathrm{c}}$ & $1162^{\mathrm{d}}$ & $1263^{\mathrm{d}}$ \\
Tensile strain $(\mathrm{mm} / \mathrm{mm})$ & $0.0029^{\mathrm{c}}$ & $0.0032^{\mathrm{c}}$ & $0.0185^{\mathrm{d}}$ & $0.0207^{\mathrm{d}}$ \\
Elastic tensile modulus $(\mathrm{GPa})$ & 190 & 193 & 61.9 & 63.8 \\
Compressive Strength $(\mathrm{MPa})$ & - & - & $907^{\mathrm{d}}$ & $827^{\mathrm{d}}$ \\
\hline
\end{tabular}

Note: Tensile strength, elastic tensile modulus and compressive strength of GFRP bars are calculated based on the root diameter.

${ }^{a}$ Obtained using immersion test in accordance with ISO 104061.1-15 (2015).

${ }^{\mathrm{b}}$ Root diameter provided by the manufacturer (Pultron 2019).

${ }^{\mathrm{c}}$ Yielding.

${ }^{\mathrm{d}}$ Ultimate.

Table 5. Experimental results of geopolymer concrete specimens tested under concentric axial load.

\begin{tabular}{lccc}
\hline Specimen & S40E0 & G40E0 & G75E0 \\
\hline$P_{l}{ }^{\text {a }}(\mathrm{kN})$ & 1175 & 1027 & 863 \\
$P_{l}{ }^{*}$ & 1.16 & 0.87 & 0.80 \\
Axial deformation corresponding to $P_{l}{ }^{*}(\mathrm{~mm})$ & 3.5 & 3.4 & 3.0 \\
${\text { Peak axial load, } P_{\text {peak }}(\mathrm{kN})}^{*}$ & 1244 & 1062 & 877 \\
$P_{\text {peak }}$ & 1.24 & 0.90 & 0.82 \\
Axial deformation corresponding to $P_{\text {peak }}{ }^{*}(\mathrm{~mm})$ & 3.8 & 3.7 & 3.1 \\
Average strain in the helices at peak load, $\varepsilon_{\text {helix }}(\mu \varepsilon)$ & 745 & 625 & 521 \\
$P_{\text {bar }}{ }^{\mathrm{b}}(\mathrm{kN})$ & 259 & 64 & 53 \\
\hline
\end{tabular}

${ }^{\mathrm{a}} P_{l}=$ Load at the end of the linear elastic stage.

${ }^{\mathrm{b}} P_{b a r}=$ Average axial load contribution by longitudinal bars at peak load.

Note: * represents the normalized load capacities of the test specimens calculated using Eq. (1).

Table 6. Experimental peak load, compressive strength, normalized load, confinement efficiency and deformability of geopolymer concrete specimens tested under different loading conditions.

\begin{tabular}{cccccc}
\hline Specimen & $\begin{array}{c}P_{\text {peak }} \\
(\mathrm{kN})\end{array}$ & $\begin{array}{c}f_{c o} \\
(\mathrm{MPa})\end{array}$ & $P_{\text {peak }}{ }^{*}=\frac{P_{\text {peak }}}{f_{c o} A_{g}}$ & $\begin{array}{c}\text { Confinement } \\
\text { efficiency }\end{array}$ & Deformability \\
\hline S40E0 & 1244 & 50 & 1.24 & 1.9 & 2.6 \\
S40E15 & 926 & 54 & 0.85 & 1.3 & 1.5 \\
S40E35 & 494 & 55 & 0.45 & 0.7 & 1.4 \\
S40B & 72 & 46 & 0.07 & - & 3.9 \\
\hline G40E0 & 1062 & 59 & 0.90 & 1.4 & 1.5 \\
G40E15 & 778 & 55 & 0.70 & 1.1 & 1.4 \\
G40E35 & 470 & 61 & 0.38 & 0.6 & 1.3 \\
G40B & 82 & 47 & 0.08 & - & 5.0 \\
\hline G75E0 & 879 & 53 & 0.82 & 1.3 & 1.3 \\
G75E15 & 734 & 62 & 0.59 & 0.9 & 1.2 \\
G75E35 & 416 & 64 & 0.32 & 0.5 & 1.1
\end{tabular}


G75B 69 47

0.07

4.4

Table 7. Experimental results of geopolymer concrete specimens tested under eccentric loads.

\begin{tabular}{lcccccc}
\hline \multirow{2}{*}{ Specimen } & \multicolumn{3}{c}{ 15 mm eccentric load } & \multicolumn{3}{c}{$35 \mathrm{~mm}$ eccentric load } \\
\cline { 2 - 7 } & S40E15 & G40E15 & G75E15 & S40E35 & G40E35 & G75E35 \\
\hline$P_{l}(\mathrm{kN})$ & 905 & 766 & 711 & 476 & 452 & 396 \\
$P_{l}{ }^{*}$ & 0.83 & 0.69 & 0.57 & 0.43 & 0.36 & 0.30 \\
Axial deform. at $P_{l}{ }^{*}(\mathrm{~mm})$ & 2.8 & 2.3 & 2.4 & 2.3 & 2.0 & 2.5 \\
Peak axial load, $P_{\text {peak }}(\mathrm{kN})$ & 926 & 778 & 734 & 494 & 470 & 416 \\
$P_{\text {peak }}{ }^{*}$ & 0.85 & 0.70 & 0.59 & 0.45 & 0.38 & 0.32 \\
Axial deform. at $P_{\text {peak }}{ }^{*}(\mathrm{~mm})$ & 2.9 & 2.4 & 2.5 & 2.5 & 2.1 & 2.7 \\
Lateral deform. at $P_{\text {peak }}{ }^{*}(\mathrm{~mm})$ & 2.7 & 2.1 & 1.6 & 3.1 & 2.1 & 3.6 \\
\hline
\end{tabular}

Table 8. Experimental results of the geopolymer concrete specimens tested under four-point bending.

\begin{tabular}{|c|c|c|c|}
\hline Specimen & S40B & G40B & G75B \\
\hline First peak load, $P_{\text {peak } 1}(\mathrm{kN})$ & 72 & 65 & 61 \\
\hline$P_{\text {peak } 1}{ }^{*}$ & 0.077 & 0.068 & 0.064 \\
\hline Midspan deflection at $P_{\text {peak } 1}{ }^{*}(\mathrm{~mm})$ & 22.2 & 32.5 & 35.5 \\
\hline Second peak load, $P_{\text {peak } 2}(\mathrm{kN})$ & - & 82 & 69 \\
\hline$P_{\text {peak2 }}{ }^{*}$ & - & 0.086 & 0.072 \\
\hline Midspan deflection at $P_{\text {peak } 2}{ }^{*}(\mathrm{~mm})$ & - & 68.3 & 72.5 \\
\hline
\end{tabular}

Note: * represents the normalized load capacities.

Table 9. Experimental load vs. bending moment capacity of geopolymer concrete specimens tested under different loading conditions.

\begin{tabular}{cccccc}
\hline Group & Specimen & $\begin{array}{c}P_{\text {peak }} \\
(\mathrm{kN})\end{array}$ & Ppeak $^{*}=\frac{P_{\text {peak }}}{f_{\text {co }} A_{g}}$ & $\begin{array}{c}\text { Lateral deformation } \\
\text { corresponding to } \\
P_{\text {peak }}(\mathrm{mm})\end{array}$ & $\begin{array}{c}\text { Bending moment } \\
\text { capacity (kN.m) }\end{array}$ \\
\hline \multirow{6}{*}{ S40 } & S40E0 & 1244 & 1.24 & - & - \\
& S40E15 & 926 & 0.85 & 2.7 & 16.4 \\
& S40E35 & 494 & 0.45 & 3.1 & 18.8 \\
& S40B & 72 & 0.077 & 22.2 & 15.6 \\
\hline \multirow{4}{*}{ G40 } & G40E0 & 1062 & 0.90 & - & - \\
& G40E15 & 778 & 0.70 & 2.1 & 13.3 \\
& G40E35 & 470 & 0.38 & 2.1 & 17.4 \\
\hline \multirow{6}{*}{ G75 } & G40B & 65 & 0.068 & 32.5 & 14.0 \\
& G75E0 & 879 & 0.82 & - & 12.2 \\
& G75E15 & 734 & 0.59 & 1.6 & 16.1 \\
& G75E35 & 416 & 0.32 & 3.6 & 13.2 \\
\hline
\end{tabular}


Note: The values for the specimens tested under four-point bending are corresponding to $P_{\text {peak } 1}$.

Table 10. Equations for confined concrete strength $\left(f_{c c}^{\prime}\right)$ and lateral confining pressure $\left(f_{l F R P}\right)$ in GFRP-RC columns.

\begin{tabular}{|c|c|c|}
\hline Sr. No. & Author and Reference & Equations \\
\hline 1 & $\begin{array}{l}\text { Pantelides et al. } \\
\text { (2013) }\end{array}$ & $\begin{array}{l}f_{c c}^{\prime}=f_{c}^{\prime}+\psi_{f} 3.3 k_{a} f_{l F R P} \\
f_{l F R P}=\frac{2 E_{F R P} A_{s p F R P} \varepsilon_{f e}}{s d_{c}}\end{array}$ \\
\hline 2 & Karim et al. (2016) & $\begin{array}{l}f_{c c}^{\prime}=k_{c} f_{c o} \\
f_{l F R P}=\frac{2 A_{h} k_{e} f_{\text {bent }}}{d_{c} s}\end{array}$ \\
\hline 3 & Maranan et al. (2016) & $\begin{array}{l}f_{c c}^{\prime}=f_{c o}^{\prime}+a\left(\rho_{f t} f_{l F R P}\right)^{b} \\
f_{l F R P}=\frac{\rho_{f t}}{2} E_{f} \varepsilon_{f t c c}\end{array}$ \\
\hline 4 & Hadhood et al. (2018) & $\begin{array}{l}f_{c c}^{\prime}=f_{c}^{\prime}\left[-1.254+2.254 \sqrt{1+\frac{7.94 f_{l F R P}}{f_{c}^{\prime}}}-2 \frac{f_{l F R P}}{f_{c}^{\prime}}\right] \\
f_{l F R P}=0.5 k_{e} f_{f b} \frac{4 A_{t}}{s^{\prime} d_{s}}\end{array}$ \\
\hline
\end{tabular}

Table 11. Normalized experimental and predicted axial load capacities of geopolymer concrete specimens.

\begin{tabular}{|c|c|c|c|c|}
\hline Specimen & \multicolumn{2}{|c|}{ S40E0 $\left(P_{\text {exp. }}{ }^{*}=1.24\right)$} & & \\
\hline Study & $P_{o}^{*}$ & $P_{o}^{*} / P_{\text {exp. }}{ }^{*}$ & & \\
\hline ACI 318-19 (ACI 2019) & 1.16 & 0.94 & & \\
\hline Specimen & \multicolumn{2}{|c|}{ G40E0 $\left(P_{\text {exp. }}{ }^{*}=0.90\right)$} & \multicolumn{2}{|c|}{ G75E0 $\left(P_{\text {exp. }}{ }^{*}=0.82\right)$} \\
\hline Study & $P_{o}^{*}$ & $P_{o}^{*} / P_{\text {exp. }}{ }^{*}$ & $P_{o}^{*}$ & $P_{o}^{*} / P_{\text {exp. }}^{*}$ \\
\hline CSA S806-12:R17 (CSA 2017) & 0.69 & 0.77 & - & - \\
\hline CSA S6-19 (CSA 2019) & 0.74 & 0.82 & - & - \\
\hline Mohammed et al. (2014) & 0.81 & 0.90 & - & - \\
\hline Afifi et al. (2014) & 0.92 & 1.02 & - & - \\
\hline Hadi et al. (2016) & 0.83 & 0.93 & - & - \\
\hline Hadhood et al. (2017) & $0.83^{+} / 0.77^{++}$ & $0.93^{+} / 0.85^{++}$ & - & - \\
\hline Pantelides et al. (2013) & 0.87 & 0.97 & 0.81 & 0.99 \\
\hline Karim et al. (2016) & 0.84 & 0.93 & 0.82 & 0.99 \\
\hline Maranan et al. (2016) & 0.67 & 0.75 & 0.71 & 0.86 \\
\hline Hadhood et al. (2018) & 0.77 & 0.85 & 0.74 & 0.90 \\
\hline
\end{tabular}

$P_{\text {exp. }}{ }^{*}$ is the maximum normalized experimental axial load carrying capacity of the column.

$P_{o}{ }^{*}$ is the maximum normalized theoretical axial load carrying capacity of the column.

$P_{o}{ }^{*} / P_{\text {exp. }}{ }^{*}$ is the ratio of the normalized theoretical and experimental axial load carrying capacity of the column.

${ }^{+}$Calculated using $k_{1}=0.85$ and $k_{2}=0.0035$. 
${ }^{++}$Calculated using $k_{1}=0.85-0.0015 f_{c}{ }^{\prime}$ and $k_{2}=0.0036$. 

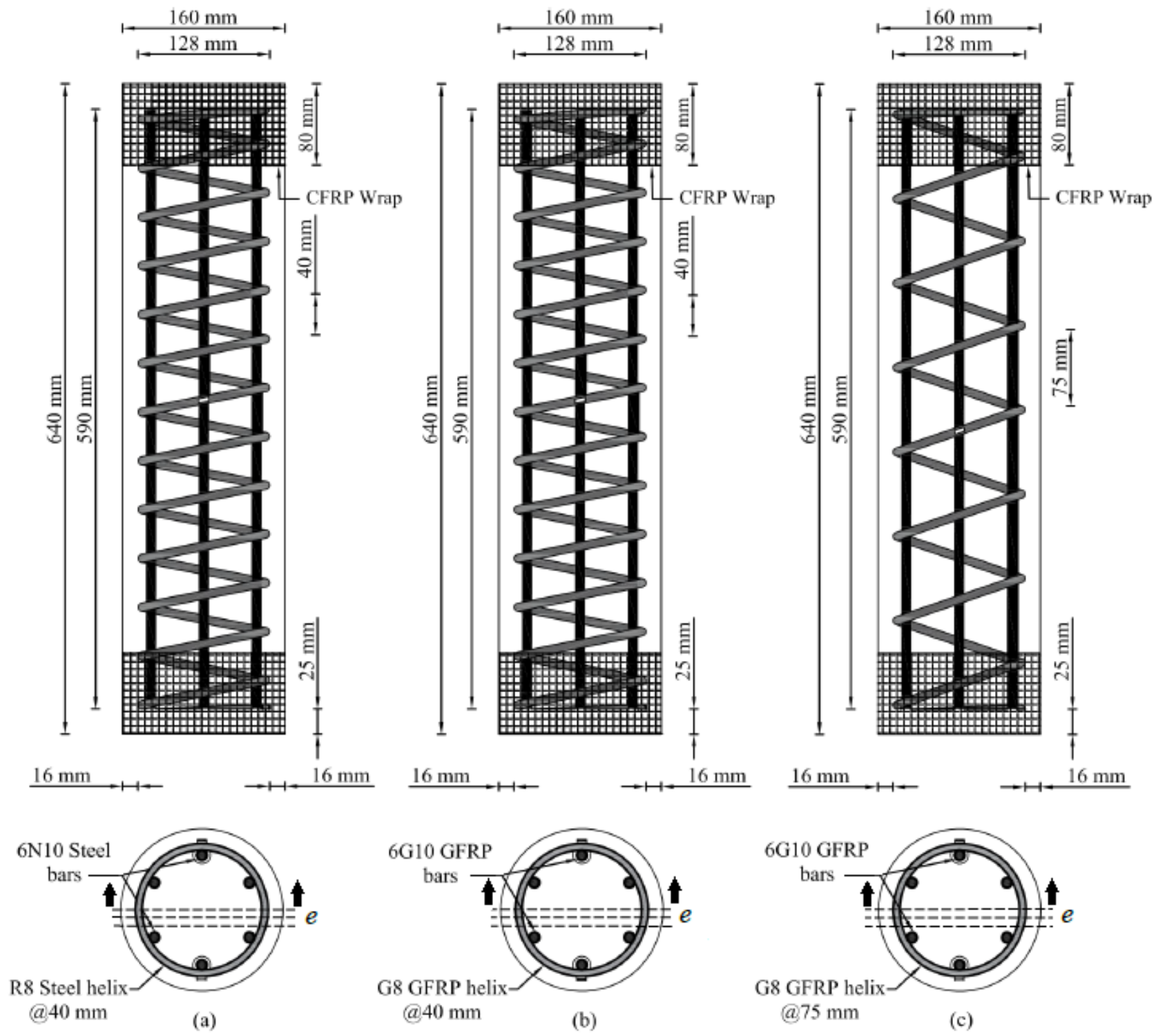

(a) $40 \mathrm{~mm}$

(b)

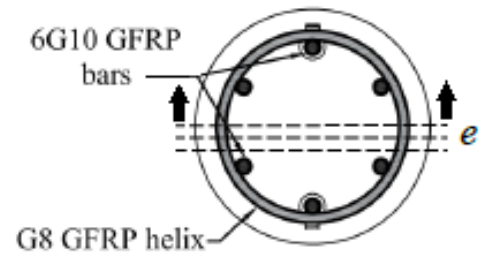

(a) $75 \mathrm{~mm}$

(c)

- Strain gauge on helices

- Strain gauge on longitudinal bars

$e=$ loading eccentricity

Fig 1 


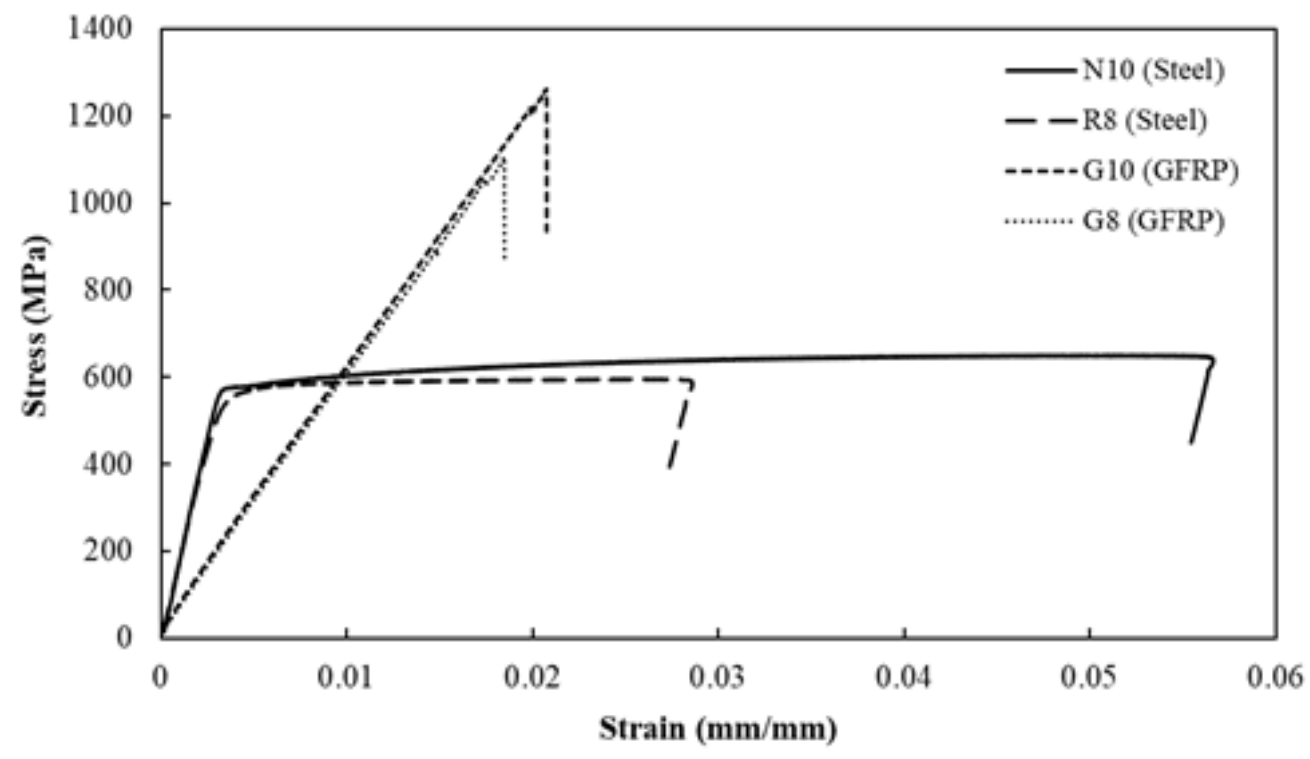

Fig 2
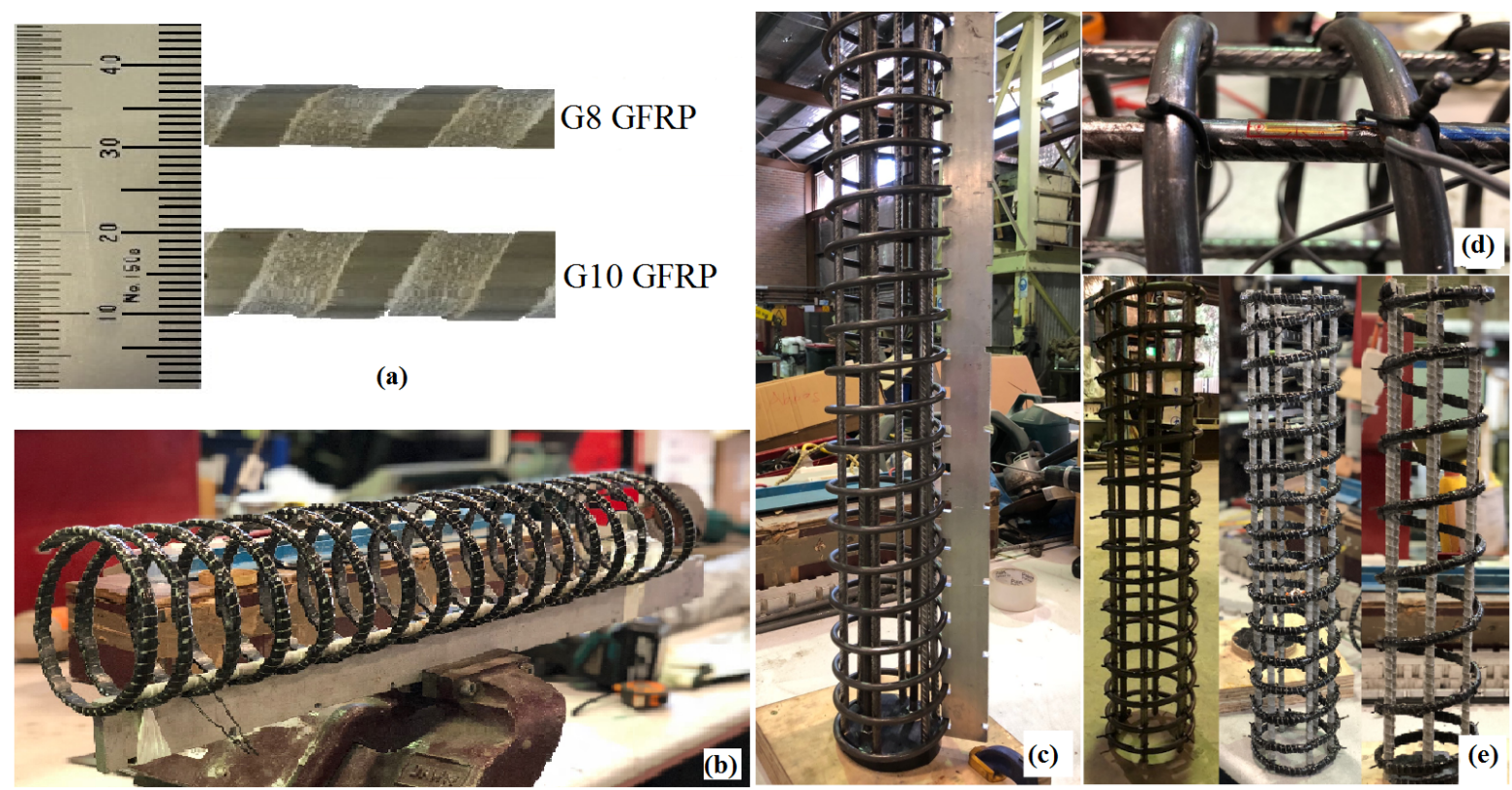

Fig 3 


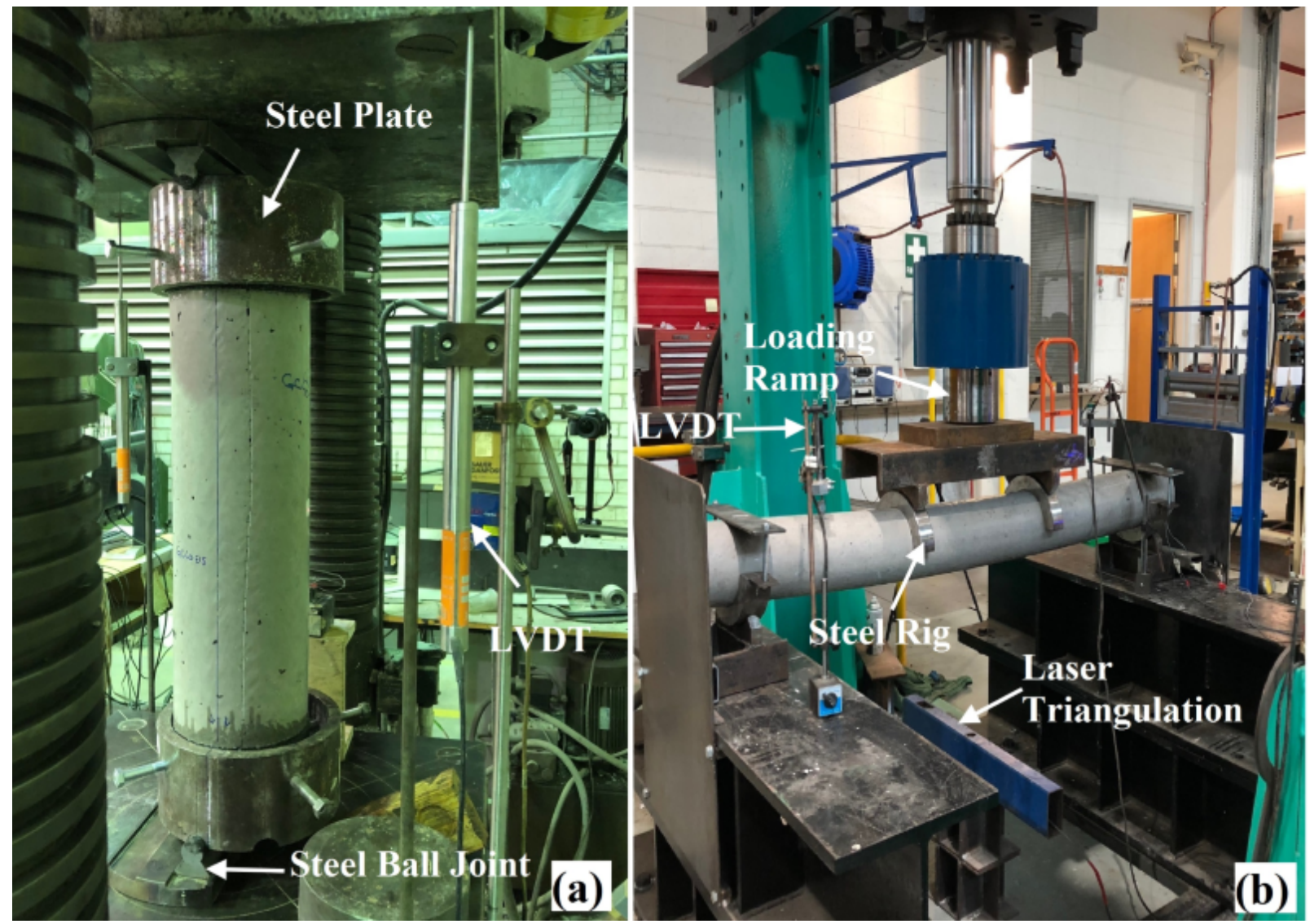

Fig 4

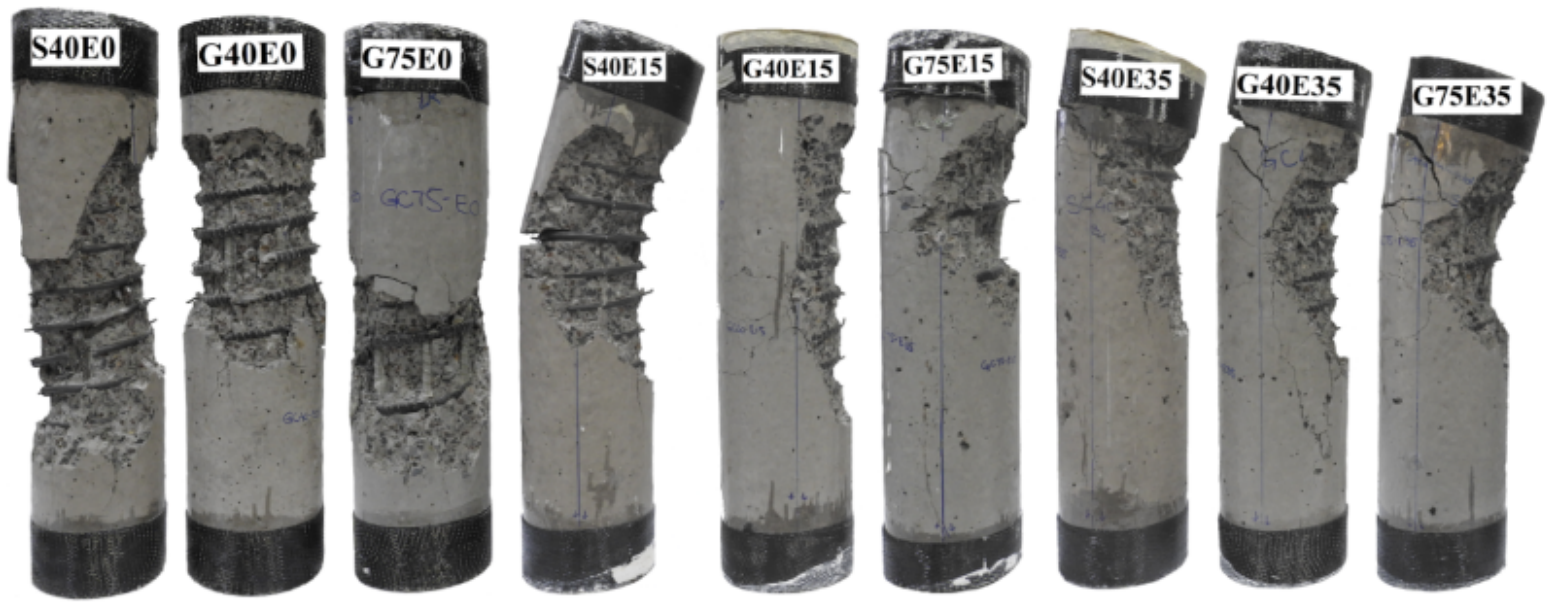

Fig 5 


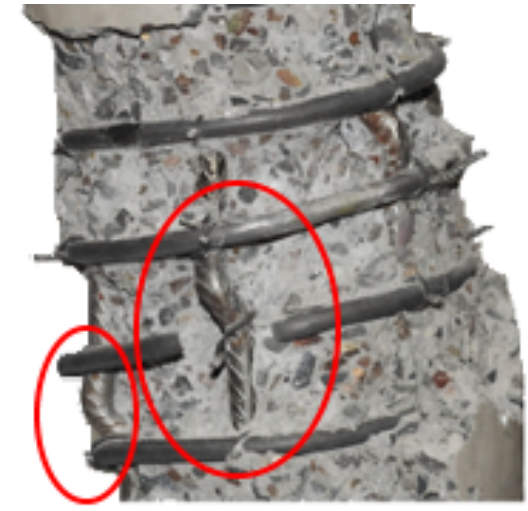

(a) Buckling of steel bars and rupture of steel helix in Specimen S40E0

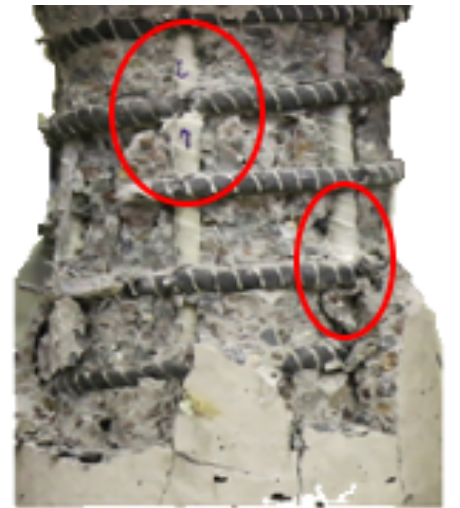

(b) Crumpling of GFRP bar and rupture of GFRP helix in Specimen G40E0

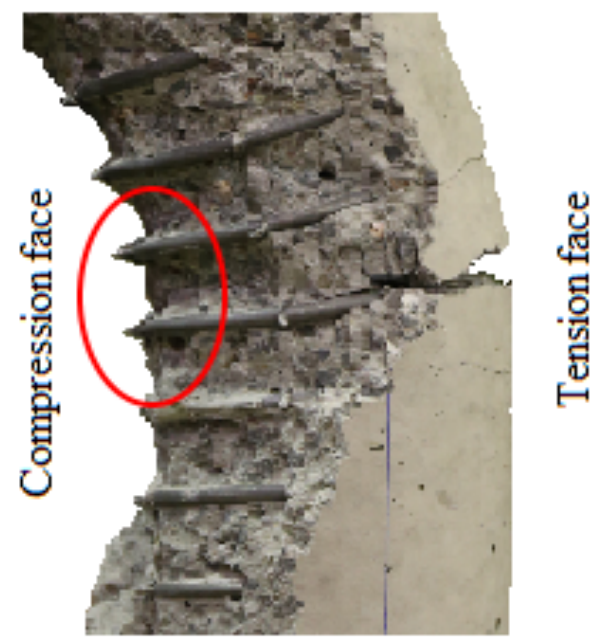

(d) Buckling of steel bars in Specimens $\mathrm{S} 40 \mathrm{E} 15$ and S40E35

Fig 6 


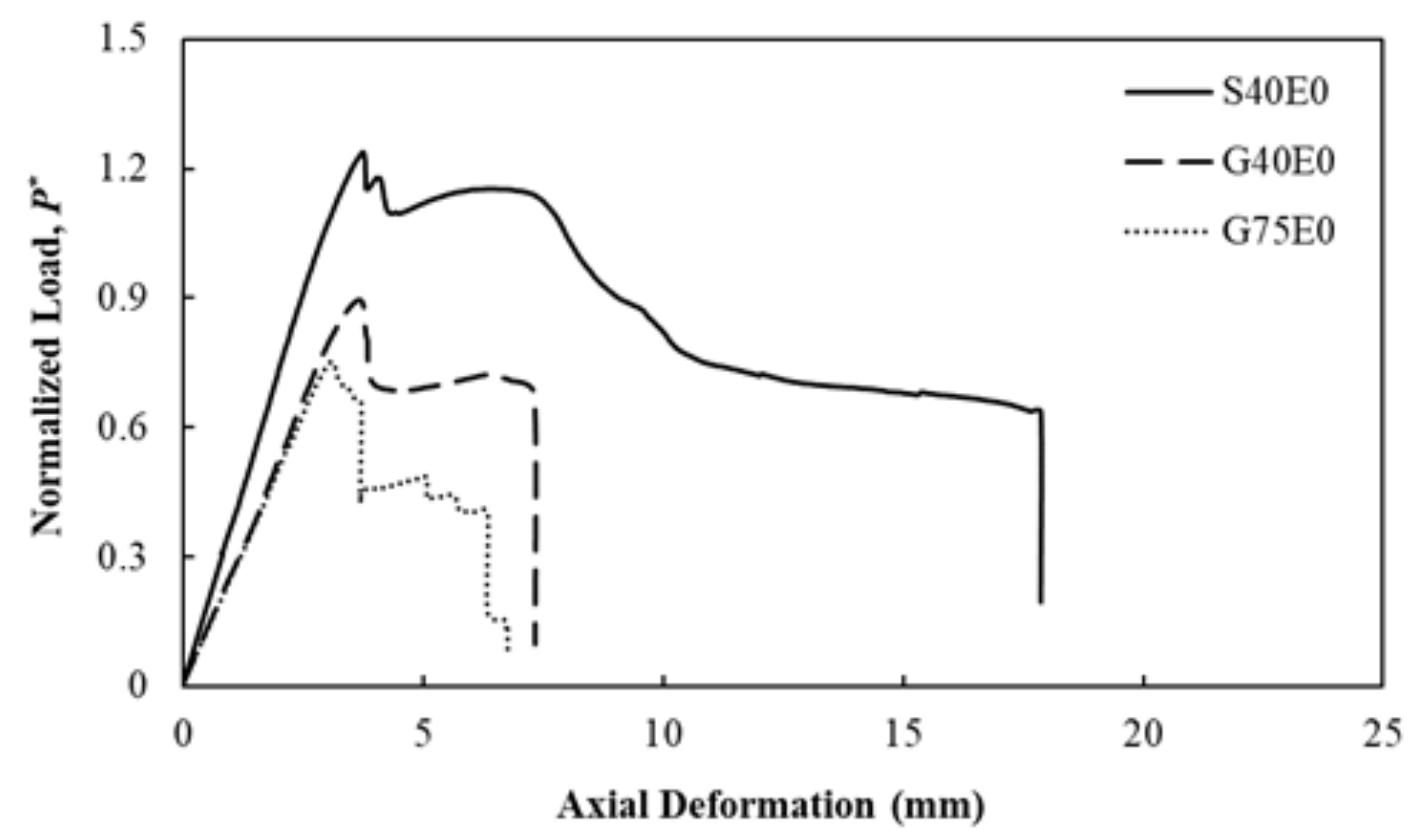

Fig 7

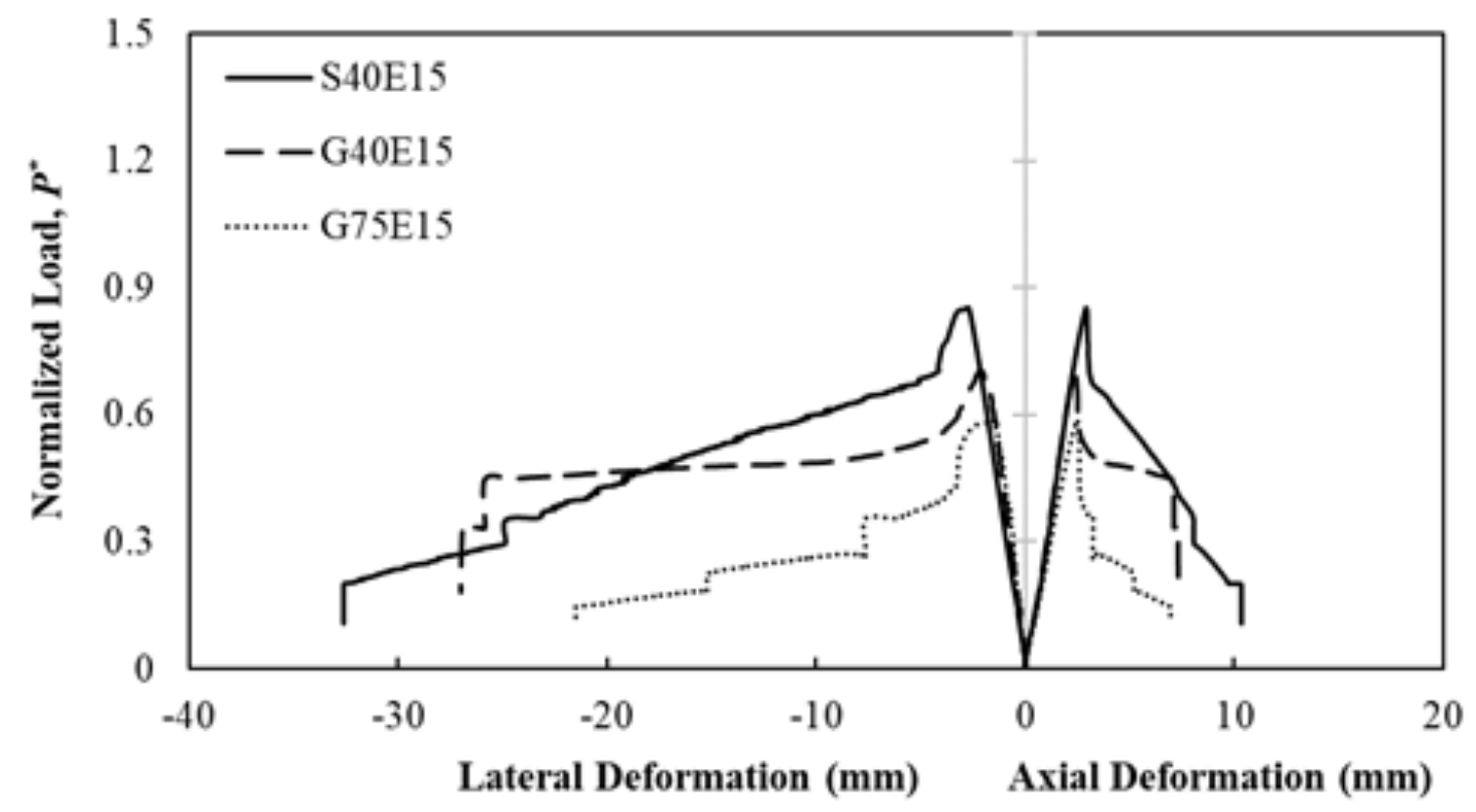

Fig 8(a) 


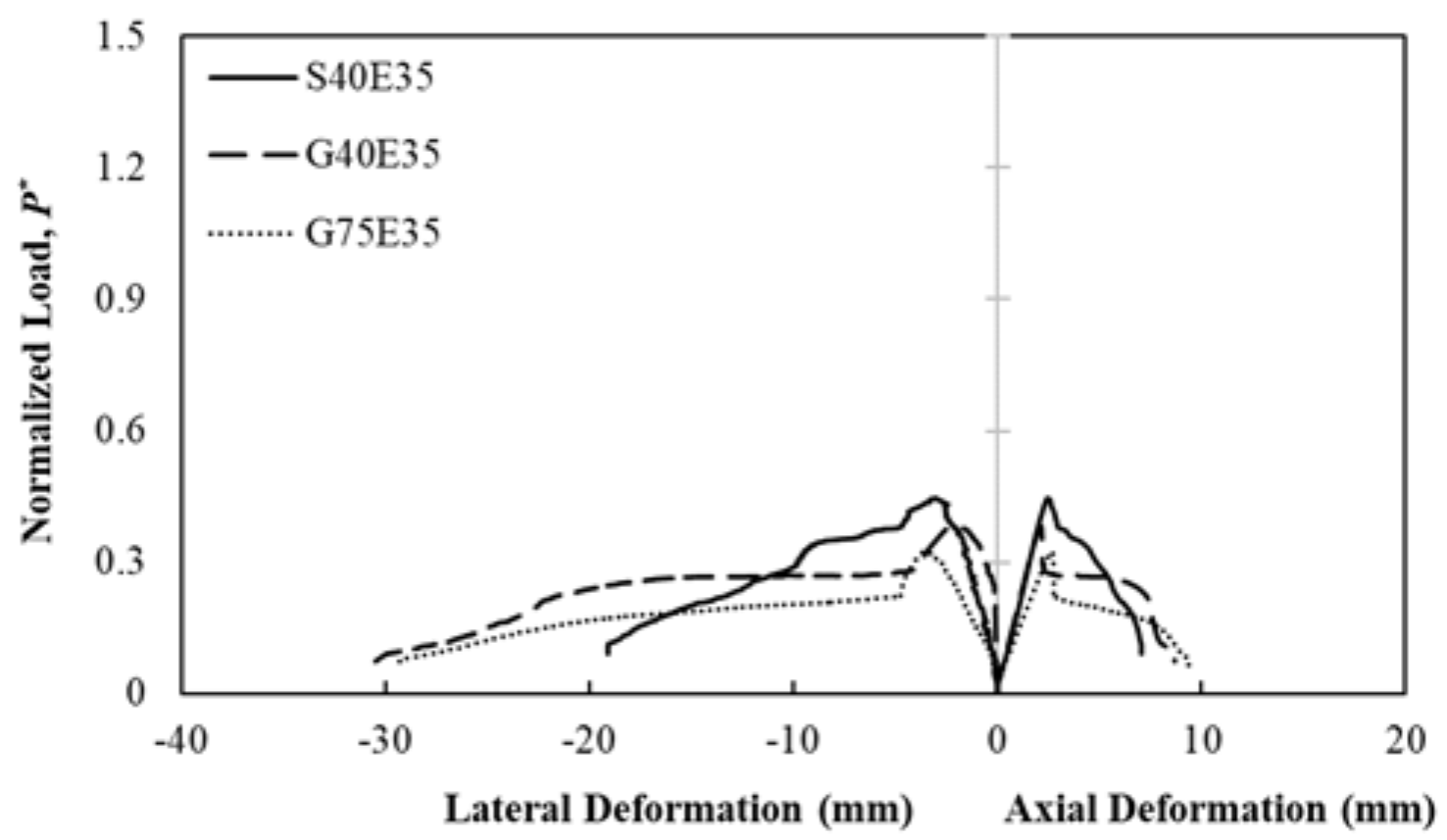

Fig 8(b)
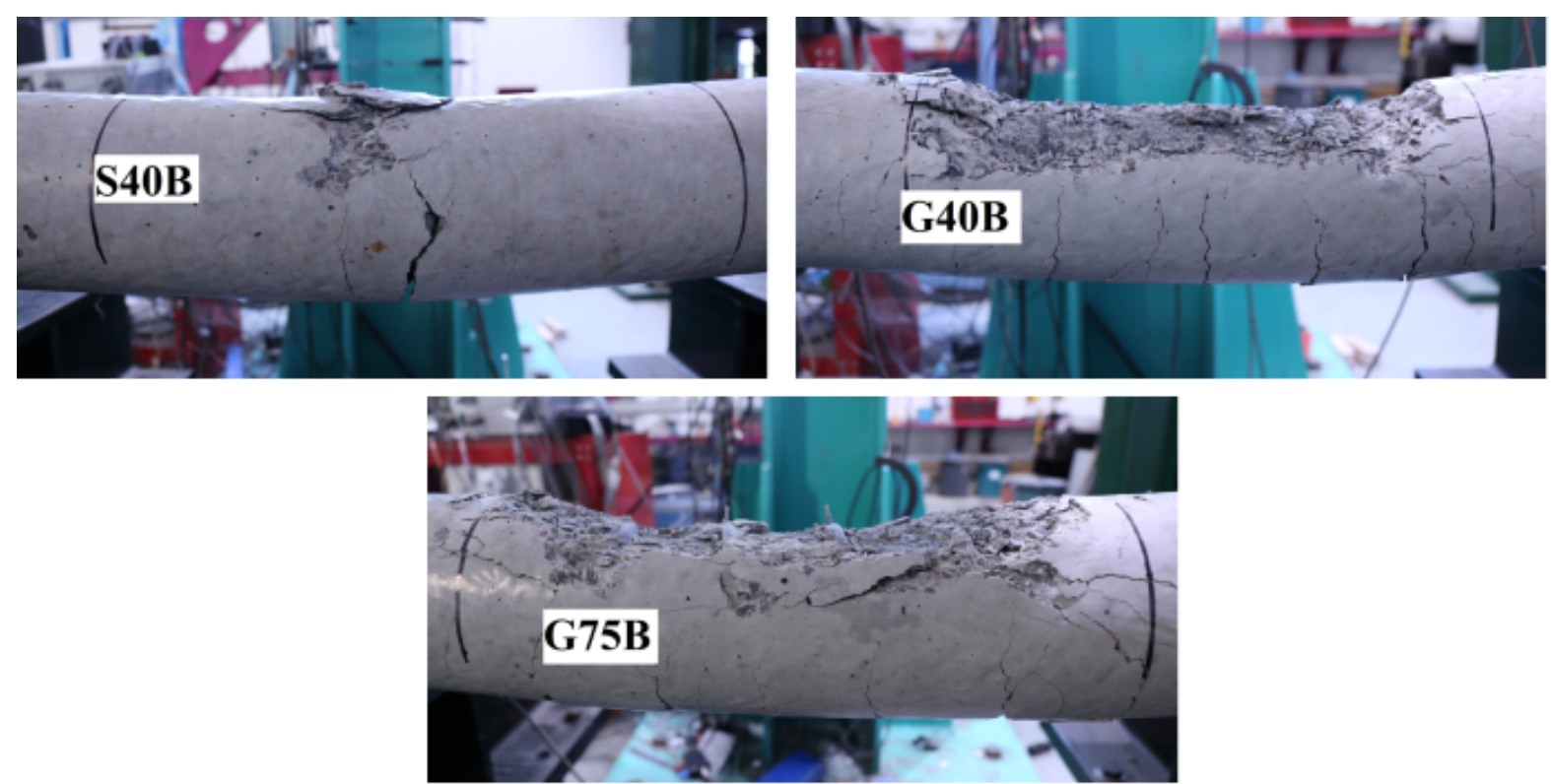

Fig 9 


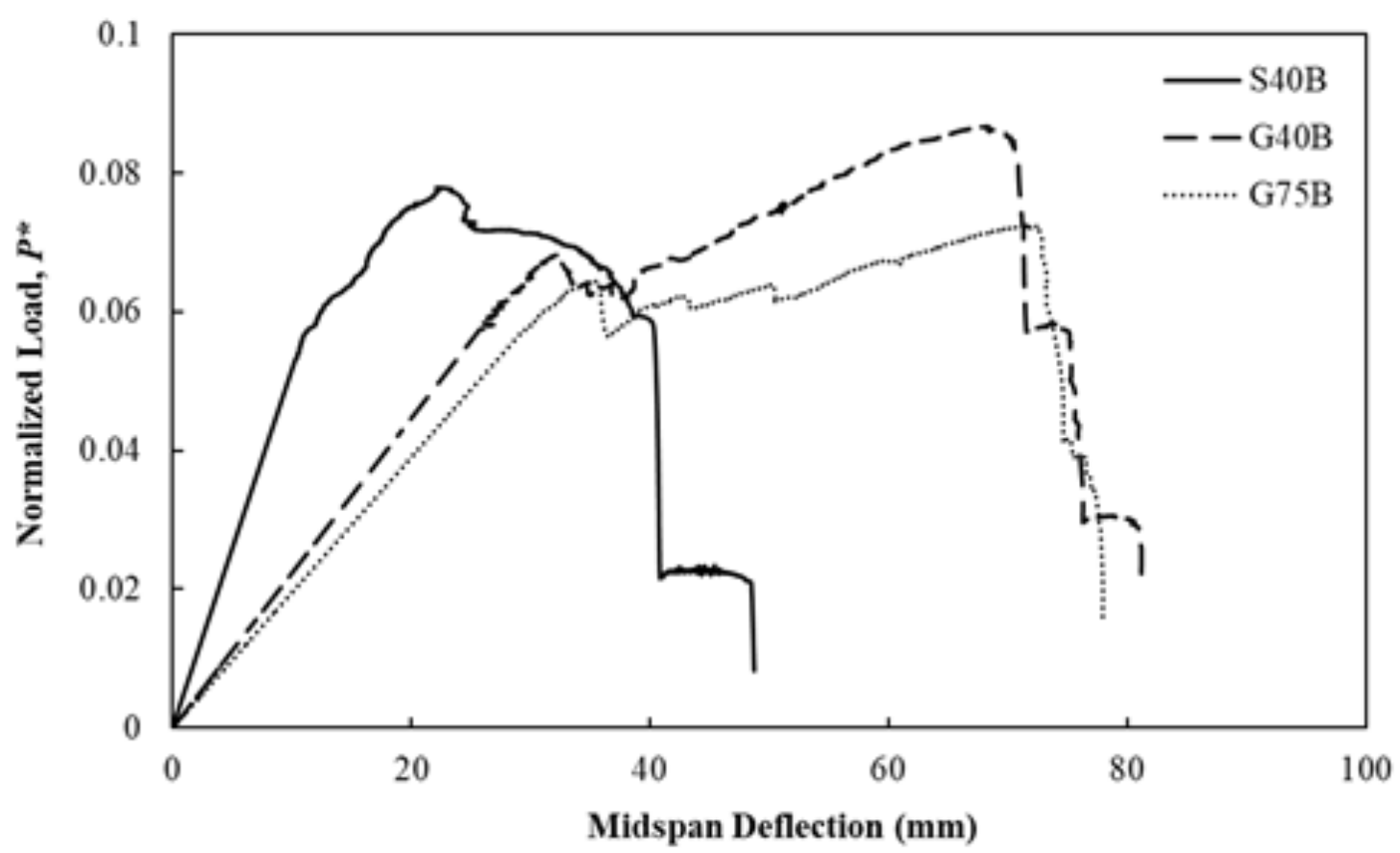

Fig 10

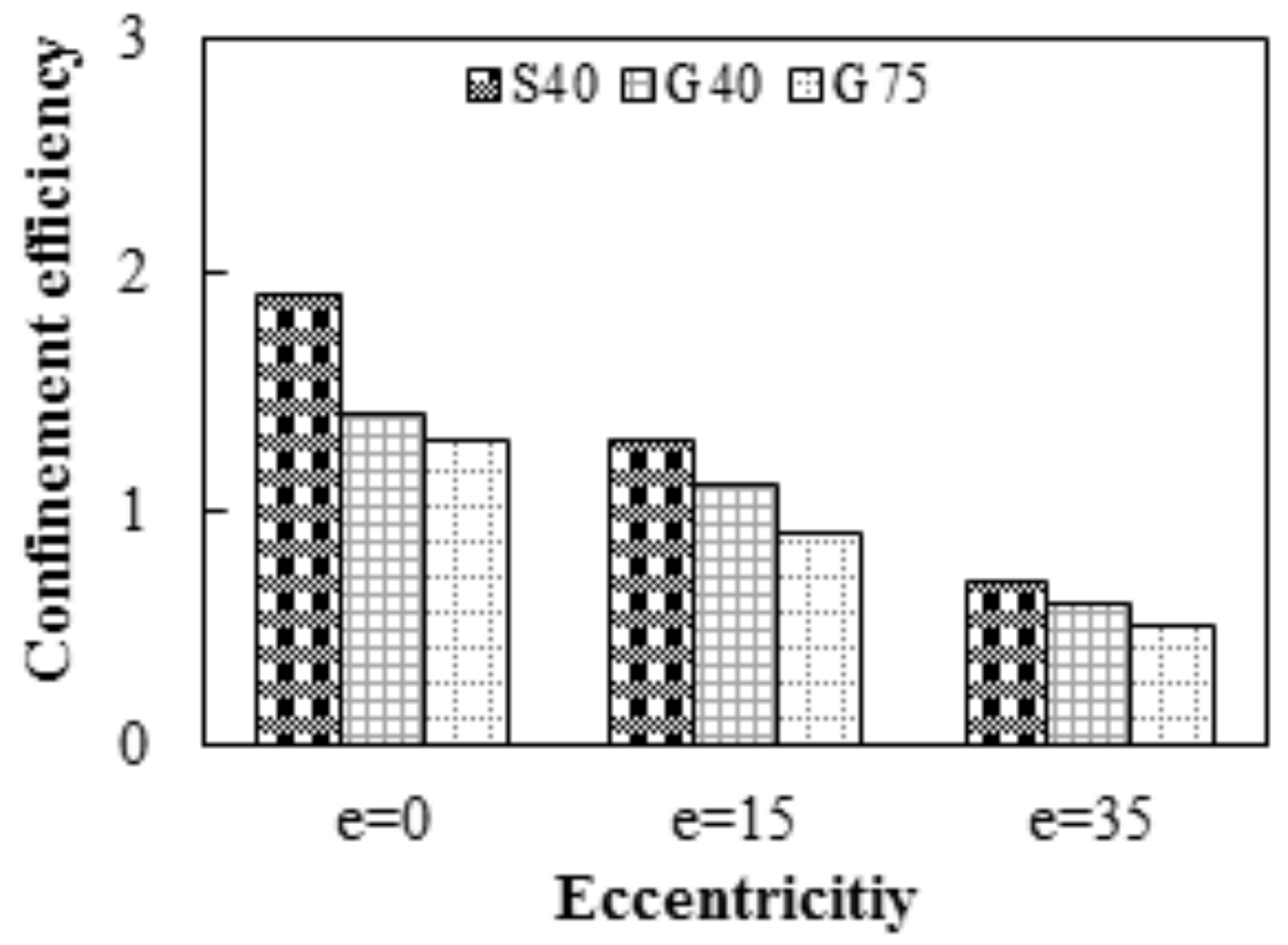

Fig 11(a) 


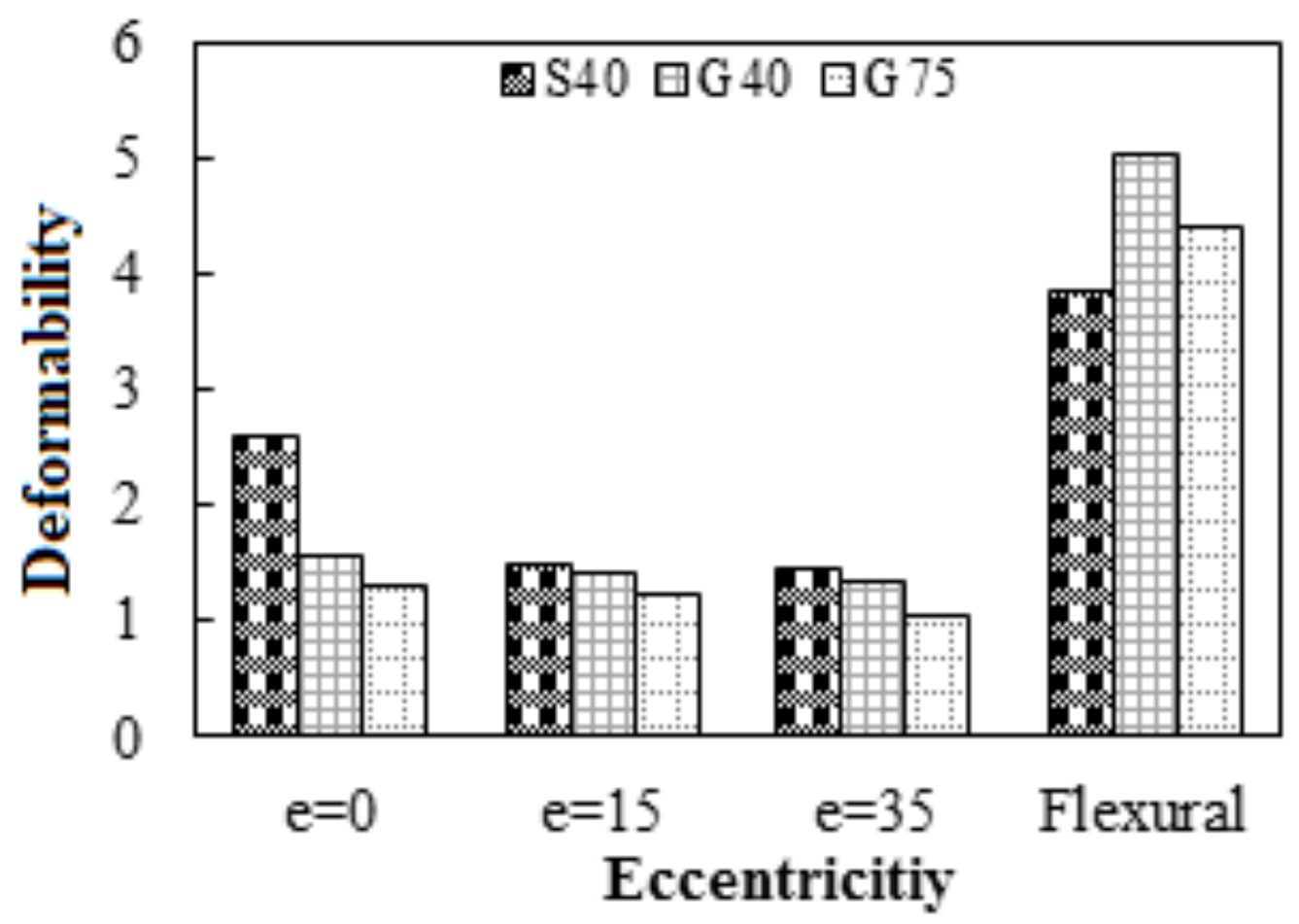

Fig 11(b)

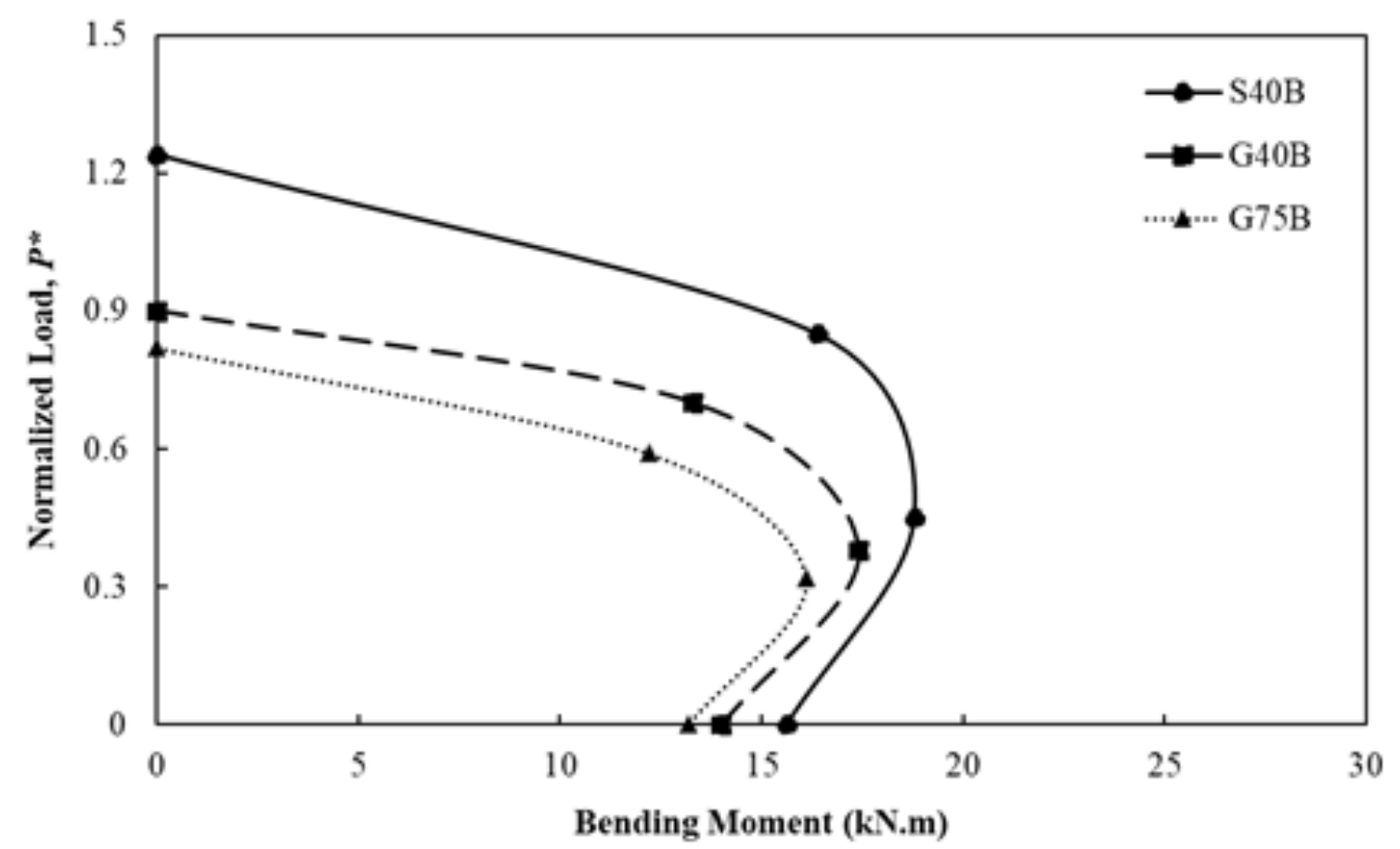

Fig 12 